\title{
Seasonal variations in fire conditions are important drivers to the trend of aerosol optical properties over the south-eastern Atlantic
}

Haochi Che ${ }^{1}$, Michal Segal-Rozenhaimer ${ }^{1,2}$, Lu Zhang ${ }^{1}$, Caroline Dang ${ }^{3,4}$, Paquita Zuidema ${ }^{5}$, Arthur J. Sedlacek III ${ }^{6}$, Xiaoye Zhang ${ }^{7}$, Connor Flynn ${ }^{8}$

$5 \quad{ }^{1}$ Department of Geophysics, Porter School, Tel Aviv University, Tel Aviv, 69978, Israel ${ }^{2}$ Bay Area Environmental Research Institute, NASA Ames Research Center, Moffett Field, CA, USA

${ }^{3}$ NASA Ames Research Center, Moffett Field, California, 94035, USA

${ }^{4}$ Universities Space Research Association, Columbia, Maryland, 21046, USA,

${ }^{5}$ Rosenstiel School of Marine and Atmospheric Sciences, University of Miami, Miami, FL, USA

$10{ }^{6}$ Brookhaven National Laboratory, Upton, NY, USA

${ }^{7}$ State Key Laboratory of Severe Weather (LASW) and Key Laboratory of Atmospheric Chemistry of CMA, Chinese Academy of Meteorological Sciences, Beijing 100081, China

${ }^{8}$ School of Meteorology, University of Oklahoma, Norman, OK, USA

Correspondence to: Haochi Che (haochiche@tauex.tau.ac.il) and Michal Segal-Rozenhaimer (msegalro@tauex.tau.ac.il)

\section{Abstract}

From June to October, southern Africa produces one-third of the global biomass burning (BB) emissions by widespread fires. $\mathrm{BB}$ aerosols are westward transported over the south-eastern Atlantic with the mid-tropospheric winds, resulting in significant radiative effects. Ascension Island (ASI) is located midway between Africa and South America. A 17-month in-situ campaign on ASI found a low single-scattering albedo (SSA) as well as a high mass absorption cross-section of black carbon (MAC $\mathrm{BC}_{\mathrm{BC}}$ ),

20 demonstrating the strong absorbing marine boundary layer in the south-eastern Atlantic. Here we investigate the monthly variations of critical optical properties of $\mathrm{BB}$ aerosols, i.e., $\mathrm{SSA}$ and $\mathrm{MAC}_{\mathrm{BC}}$, during the $\mathrm{BB}$ seasons and the driving factors behind these variations. Both SSA and $\mathrm{MAC}_{\mathrm{BC}}$ increase from June to August and decrease in September and October. The average SSA during the BB seasons is 0.81 at $529 \mathrm{~nm}$ wavelength, with the highest mean $\sim 0.85$ in October and the lowest $\sim 0.78$ in August. The absorption enhancement $E_{\text {abs }}$ derived from the $\mathrm{MAC}_{\mathrm{BC}}$ shows similar trends with SSA, with the average

25 during the whole $\mathrm{BB}$ seasons at $\sim 1.96$ and $\sim 2.07$ in 2016 and 2017. As the $\mathrm{E}_{\text {abs }}$ is higher than the $\sim 1.5$ commonly adopted value by climate models, this result suggests the marine boundary layer in the south-eastern Atlantic is more absorbing than model simulations. We find the enhanced ratio of $\mathrm{BC}$ to $\mathrm{CO}(\mathrm{BC} / \triangle \mathrm{CO})$ is well correlated with SSA and MAC $\mathrm{BC}$, providing a simple way to estimate those aerosol optical characteristics in the south-eastern Atlantic. The exponential function we proposed can approximate SSA and $\mathrm{MAC}_{\mathrm{BC}}$ with $\mathrm{BC} / \Delta \mathrm{CO}$, and can better capture the growth of SSA as the decrease of $\mathrm{BC} / \Delta \mathrm{CO}$,

30 especially when $\mathrm{BC} / \triangle \mathrm{CO}$ is small. $\mathrm{BC} / \Delta \mathrm{CO}$ is influenced by combustion conditions and aerosol scavenging. From the analysis of the location of BB burning, the primary source fuel, the water content in the fuel, combined with the mean cloud cover and precipitation in the transport areas of $\mathrm{BB}$ plume, we conclude that the increase in $\mathrm{BC} / \Delta \mathrm{CO}$ from June to August is likely to be caused by burning becoming more flaming. The reduction in the water content of fuels may be responsible for the changing 
of the burning conditions during these periods. The decrease in $\mathrm{BC} / \Delta \mathrm{CO}$ in September and October may be caused by two factors, one being a lower proportion of flaming conditions, possibly associated with a decrease in mean surface wind speed in the burning area, and the other being an increase in precipitation in the BB transport pathway, leading to enhanced aerosol scavenging, which ultimately results in an increase in SSA and $\mathrm{MAC}_{\mathrm{BC}}$.

\section{Introduction}

Biomass burning (BB) is the largest source of primary carbonaceous aerosols and the second-largest source of reactive trace gases in the atmosphere (Akagi et al., 2011; Andreae, 2019; Andreae and Merlet, 2001; Guenther et al., 2006; van der Werf et al., 2017). Aerosols emitted from BB have profound implications for air quality (Brey et al., 2018; Chen et al., 2017; Reisen et al., 2013), health (Johnston et al., 2012; Naeher et al., 2007; Roberts et al., 2011) and climate (Bond et al., 2013; Che et al., 2021; Freire et al., 2020; Malavelle et al., 2019; Thornhill et al., 2018). From June through October, southern Africa produces around one-third of the global BB emission by widespread fires across the savannah region (Roberts et al., 2009; van der Werf et al., 2017). These BB aerosols are westward transported by mid-tropospheric winds over the coincident south-eastern Atlantic (SEA) stratocumulus clouds (Adebiyi and Zuidema, 2016), and can result in significant radiative effects affecting the regional climate (Chand et al., 2009; Che et al., 2021, 2022b; Gordon et al., 2018; Lu et al., 2018; Sakaeda et al., 2011; Stier et al., 2013; Wilcox, 2012). Despite extensive studies, the radiative forcing associated with BB aerosol in the south-eastern Atlantic remains uncertain (Mallet et al., 2021; Doherty et al., 2022).

50 Black carbon (BC) emitted from BB is the primary absorbent particle that directly impacts the single-scattering albedo (SSA), resulting in a significant warming effect dominating the direct radiative forcing of BB aerosols (Mallet et al., 2020; Pokhrel et al., 2016). Since SSA is one of the largest sources of uncertainty in estimating the aerosol direct and semi-direct radiative forcings (Jiang et al., 2006; McComiskey et al., 2008), it is critical to constrain models with observed SSA. Previous studies generally consider the SSA of BB aerosol ranging from 0.8 to 0.9 at $550 \mathrm{~nm}$ (Wu et al., 2020; Eck et al., 2013; Johnson et al., 2008; Pistone et al., 2019), while an extremely low SSA ( 0.75 at $550 \mathrm{~nm})$ was observed on Ascension Island (ASI) by Zuidema et al. (2018), suggesting a strong absorbing marine boundary layer in the south-eastern Atlantic. Those SSA values are lower than flight observations near ASI (Wu et al., 2020) during CLARIFY (CLoud-Aerosol-Radiation Interactions and Forcing for Year 2017) campaign, and represent the lowest values compared to all previously reported observations of African BB aerosols (e.g. Pistone et al., 2019), motivating us to investigate the causes and variations of their occurrence. In addition

60 to SSA, the mass absorption cross-section of $\mathrm{BC}(\mathrm{MAC} B \mathrm{BC})$ is an essential parameter in quantifying $\mathrm{BB}$ aerosol absorbing capacity and is a fundamental input in climate models (Bond et al., 2013). For fresh BC, MACBC falls within a narrow range of $7.5 \pm 1.2 \mathrm{~m}^{2} \mathrm{~g}^{-1}$ at $550 \mathrm{~nm}$, while with ageing and internal mixing of $\mathrm{BC}, \mathrm{MAC} \mathrm{BC}_{\mathrm{BC}}$ can increase by approximately $50 \%$ (Bond et al., 2013). The increased absorption results from coatings on BC particles through the so-called lensing effect and is often represented by an absorption enhancement (Eabs). Observations in different global regions have reported varying Eabs, 
65 depending on the coating thickness and mixing states of BC particles (Xu et al., 2018). Zuidema et al. (2018) demonstrated a high $\mathrm{MAC}_{\mathrm{BC}}$ observed on ASI, suggesting the $\mathrm{E}_{\mathrm{abs}}$ can be higher than 2, which is usually observed in heavily polluted areas (Xu et al., 2018). The Eabs observed on ASI is significantly higher than the generally adopted value of $\sim 1.5$ by current climate models (Cappa et al., 2012; Bond et al., 2013), indicating that the marine boundary layer in the south-eastern Atlantic is more absorbing than the model simulations. All these aerosol optical properties measured on ASI suggest current models may not be able to well simulate the marine boundary layer in the south-eastern Atlantic, raising questions about the accuracy of climate models in this region.

During the BB season, the physical and chemical properties of BB aerosols change with variations in combustion conditions, source fuel, and meteorological conditions, resulting in variations in the optical characteristics of BB aerosols (Pokhrel et al., 2021). Although satellite and surface-based sun photometer observations are able to estimate long-term SSA variation, the 75 presence of the extensive clouds make it difficult to retrieve SSA in the marine boundary layer in the SEA (Haywood et al., 2004; Eswaran et al., 2019). Recent aircraft campaigns conducted in this region have provided information on the optical

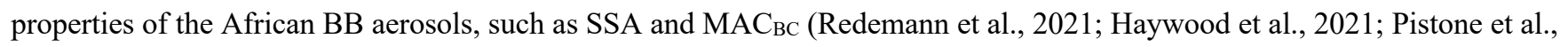
2019). However, these campaigns are of short duration and thus unable to provide a long-term dataset on the variation of optical properties of BB aerosols in the marine boundary layer as the African plume transects to ASI.

80 From 1 June 2016 to 31 October 2017, the LASIC (Layered Atlantic Smoke Interactions with Clouds) observation campaign was carried out on ASI, which offers, for the first time, the opportunity to collect a long-term dataset on those fundamental aerosol properties (Zuidema et al., 2018b, 2016). The island is midway between Africa and South America, and located within the trade wind shallow cumulus regime with the deepening boundary layer known to entrain free tropospheric plumes during the African BB seasons (Adebiyi and Zuidema, 2016). With the 17 months of continuous observations, LASIC enables a

85 detailed study of the variation of the optical properties of BB aerosols and the factors influencing them. Therefore, here, we examined the monthly variations of $\mathrm{SSA}, \mathrm{MAC}_{\mathrm{BC}}$, and $\mathrm{E}_{\mathrm{abs}}$ measured on $\mathrm{ASI}$ during the two-year $\mathrm{BB}$ seasons, and explored the factors responsible for these variations. The data and method we used are described in Sect. 2, the variation of SSA, MAC $\mathrm{BC}_{\mathrm{BC}}$ and $\mathrm{E}_{\mathrm{abs}}$ are discussed in Sect. 3.1. Then relations between these aerosol optical properties (SSA and MACBC) and $\mathrm{BC} / \triangle \mathrm{CO}$ (introduced and discussed in Sect. 2) are discussed in Sect 3.2. The potential drivers behind the changes in $\mathrm{BC} / \Delta \mathrm{CO}$ are further 90 discussed in Sect. 4. Section 5 offers conclusions. 


\section{Method}

\subsection{In-situ field observations}

LASIC campaign was carried out on the Atmospheric Radiation Measurement (ARM) Mobile Facility 1 site at Ascension

Island, located at a latitude of -7.97 , longitude of-14.35 and altitude of $340.8 \mathrm{~m}$. A more detailed description of the sampling location and instruments can be found in the campaign report (Zuidema et al., 2018a). Here we provide a brief introduction of instruments and data we have used in this paper.

Carbon monoxide (CO) concentration was measured by Los Gatos Model ICOS CO/N2O/H2O Analyzer. The aerosol absorption coefficient is derived by Particle Soot Absorption Photometer (PSAP, Radiance Research Inc), and the data are corrected as an average of the Virkkula (2010) and Ogren (2010) corrections. The aerosol scattering coefficient is measured by a nephelometer. Absorptions were measured at 464, $529 \mathrm{~nm}$, and $648 \mathrm{~nm}$ wavelengths, while scattering was at 450, 550, and $700 \mathrm{~nm}$. The scattering coefficients were then adjusted to the wavelength of the absorptions using the scattering Ångström exponent to derive the SSAs. Only data with absorption coefficients greater than $5 \mathrm{Mm}^{-1}$ were used to calculate the SSA. All data is applied with standard temperature and pressure correction (STP). Note that the aerosol absorption and scattering coefficients were measured at different relative humidity, as PSAP measured dry aerosols with the estimated relative humidity $(\mathrm{RH}) \leq 25 \%$, while the nephelometer measured aerosols with RH spanning $45 \%$ to $60 \%$. Since the scattering measurement is conducted on a sample that is not as dry as the absorption, the SSA observed on ASI likely represent an upper bound to the true SSA. The refractive BC was derived from Single Particle Soot Photometer (SP2, Droplet measurement Technologies Inc) measurements. The $\mathrm{MAC}_{\mathrm{BC}}$ is calculated as the ratio of absorption coefficient and the $\mathrm{BC}$ mass concentration. To minimise instrument accuracy errors in the derived $\mathrm{MAC}_{\mathrm{BC}}$, only data with $\mathrm{BC}$ greater than $70 \mathrm{ng}$ and absorption coefficients greater than $5 \mathrm{Mm}^{-1}$ were used. The absorption enhancement $\mathrm{E}_{\mathrm{abs}}$ was calculated by dividing the $\mathrm{MAC}_{\mathrm{BC}}$ from our observations with that characteristic of fresh uncoated BC $\left(7.5 \pm 1.2 \mathrm{~m}^{2} \mathrm{~g}^{-1}\right.$ at a wavelength of $550 \mathrm{~nm}$ by Bond and Bergstrom (2006)), and assuming the absorption Ångström exponent (AAE) of fresh BC as 1. Recent studies have shown that the AAE of fresh BC can vary from 0.8 to 1.4 (Liu et al., 2018), thus we further estimated a possible Eabs range based on the variation of the AAE.

115 We also calculated the contribution of brown carbon $(\mathrm{BrC})$ to total absorption at a wavelength of $464 \mathrm{~nm}$, based on the AAE derived from the observations using the following equation:

$$
f_{B r C}=1-\frac{M A C_{529}}{M A C_{464}}\left(\frac{529}{464}\right)^{A A E_{529-648}}
$$

where the $f_{\mathrm{BrC}}$ is the fraction of absorption at $464 \mathrm{~nm}$ due to $\mathrm{BrC}$, and $\mathrm{MAC}_{464}$ and $\mathrm{MAC}_{529}$ are the measured $\mathrm{MAC}_{\mathrm{BC}}$ at 464 and $529 \mathrm{~nm}$ wavelengths, respectively. AAE529-648 is the absorption Ångström exponent calculated between 529 and $648 \mathrm{~nm}$.

120 This method is similar to the one used by Taylor et al. (2020), while it may bring uncertainties as the AAE of BC is not always 1 , and the $\mathrm{MAC}_{\mathrm{BC}}$ at longer wavelengths might contain contributions from other absorbing materials, such as dust (Lack and 
Langridge, 2013; Zhang et al., 2022). Note that most of the BC observation for September and October 2017 is unreliable due to issues with the inlet system. Therefore, the $\mathrm{MAC}_{\mathrm{BC}}, \mathrm{E}_{\mathrm{abs}}$, and $\mathrm{f}_{\mathrm{BrC}}$ for this period are also unreliable, and hence, excluded from our analysis.

125 The enhanced ratio of $\mathrm{BC}$ to $\mathrm{CO}(\triangle \mathrm{BC} / \triangle \mathrm{CO})$ is often used to indicate the emission conditions of the fire source, as the lifetime of $\mathrm{CO}$ is approximately one month, so the ratio of $\Delta \mathrm{BC} / \Delta \mathrm{CO}$ removes the effect of diffusion. $\Delta$ represents the difference between observed and background concentrations. The background concentration of $\mathrm{BC}$ was considered to be zero, whereas the background concentration of $\mathrm{CO}$ was taken as the lowest $5^{\text {th }}$ percentiles of the observations per month and can be found in Fig. $\mathrm{S} 1$ (supplement). Hence, $\Delta \mathrm{BC} / \Delta \mathrm{CO}$ is equal to $\mathrm{BC} / \Delta \mathrm{CO}$, the ratio that will be used in the ensuing analysis. Note the $\mathrm{CO}$ was converted to the same mass unit as the $\mathrm{BC}$; therefore, $\mathrm{BC} / \Delta \mathrm{CO}$ is a unitless parameter.

\subsection{Filter samples}

During August 2017, filter samples were collected from FAAM's filters systems on the UK's Bae-146 aircraft near ASI. Samples were deposited on Paella TEM grids, and analysed with a JEOL TM JEM-2010F FEG-TEM with a ThermoNoran ${ }^{\text {TM }}$ energy dispersive X-ray detector (EDX), with more detailed information described by Dang et al. (2021). There were 17

135 samples collected near ASI, while only two samples were collected inside the marine boundary layer and close to ASI (within $5 \mathrm{~km}$ ) to represent the composition and mixing of the aerosol measured on ASI. Between these two samples, BB aerosols were collected on just one filter. Therefore, although this sample (sampled at 2017/08/24 9:43-9:49, at $319.4 \mathrm{~m}$ ) may provide information on the chemical composition of BB aerosols, it is not statistically representative.

\subsection{Satellite data}

140 The fire and land cover data were obtained from the Moderate Resolution Imaging Spectroradiometer (MODIS) sensors onboard the Terra and Aqua satellites. The active fire data was obtained from the MODIS Thermal Anomalies Collection 6.1 (Giglio et al., 2016, p.6), which provide monthly mean fire radiative power at the centre of a $1 \mathrm{~km}$ pixel. To identify the main areas of combustion, the accumulated fire counts were calculated each month with the confidence greater than or equal to nominal for each pixel, then areas with the fire count $>500$ are considered the main burning areas. The land cover data was

145 taken from the MODIS version 6, which provide annual land cover types derived from six different classification schemes (Sulla-Menashe et al., 2019). Here we used the Land Cover Type 3 product with the annual leaf area index (LAI) classification, to show the land cover types on the African continent. Normalized Difference Moisture Index (NDMI) is used to determine vegetation moisture content. It is derived from the Landsat 8 Operational Land Imager (OLI)/Thermal Infrared Sensor (TIRS surface reflectance (Wilson and Sader, 2002), and can be used to monitor fuel levels in fire-prone areas. 


\subsection{Meteorological data}

The monthly averaged surface wind, low-level cloud fraction, and total precipitation data are all from the ECMWF ERA5 reanalysis dataset, which is the fifth-generation reanalysis for the global climate and weather (Hersbach et al., 2020). The data is at $0.25^{\circ} \times 0.25^{\circ}$ resolution. The surface wind anomalies are calculated using the monthly deviations from the averages during the BB season (June-October) in 2016 and 2017 combined.

\section{2.4 Trajectories and PSCF analysis}

The Hybrid Single-Particle Lagrangian Integrated Trajectory (HYSPLIT) model (Stein et al., 2015) was used to generate 7day back trajectories. Trajectories were initiated from the coordinate of the sampling location, but at altitudes of 500 and 2000 $\mathrm{m}$, using the Global Data Assimilation System (GDAS) database with $1^{\circ}$ spatial resolution. One trajectory was generated per hour during the entire BB season in 2016 and 2017. However, airmass trajectories based on HYSPLIT only reflect the large-

160 scale subsidence and cannot capture entrainment, which has a significant contribution to the BB aerosols observed on the ASI (Diamond et al., 2018). Backward trajectories initiated from Ascension Island at an altitude of $500 \mathrm{~m}$ were largely distributed over the clean oceanic region in the southeast throughout the BB season and rarely touched the African continent (Fig. S2). Therefore, we only show the trajectories in the free troposphere (initiated at $2000 \mathrm{~m}$ ) to show potential BB aerosol transport paths prior to entrainment.

165 The potential source contribution function (PSCF) (Polissar et al., 2001) is widely used to identify the probable location of the emission sources and pathways that affect the receptor site (Koçak et al., 2009; Karaca et al., 2009). We calculated the PSCF with $\mathrm{BC} / \Delta \mathrm{CO}>$ and $\leq 0.0034$, respectively. This threshold is taken as a proxy that represents the different combustion conditions and is discussed in detail in section 4.1. The PSCF in the sub-region $i j$ at each $\mathrm{BC} / \triangle \mathrm{CO}$ category $X$ is given by the following equation:

$$
\operatorname{PSCF}_{X_{-} i j}=\frac{m_{X_{-} i j}}{n_{i j}}
$$

where $m_{X_{-} j}$ is the number of segment trajectory endpoints in the $i j$ th cell at a certain category $X$ of $\mathrm{BC} / \Delta \mathrm{CO}(>$ or $\leq 0.0034)$, and $n_{i j}$ is the total number of air masses falling into the $i j$ th cell. The value of the PSCF represents a conditional probability where a specific type of $\mathrm{BC} / \Delta \mathrm{CO}(>$ or $\leq 0.0034)$ is related to the passage of air parcel through the $i j$ th cell. High PSCF cells indicate areas of high potential contributions to current selected $\mathrm{BC} / \triangle \mathrm{CO}$, and the trajectories passing over these cells contribute to the major transport pathways at the receptor site. To reduce the uncertainty of PSCF resulting from small $n_{i j}$, an arbitrary weight function $W_{i j}$ is used to multiply by the PSCF, as introduced by Polissar et al. (2001). 


$$
W_{i j}=\left\{\begin{array}{lr}
1.0 & n_{i j}>2 \times A v g \\
0.75 & A v g<n_{i j} \leq 2 \times A v g \\
0.5 & 0.5 \times A v g<n_{i j} \leq A v g \\
0.15 & 0<n_{i j} \leq 0.5 \times A v g
\end{array}\right.
$$

where $A v g$ is the average number of endpoints in each cell.

\section{Results}

3.1 Monthly variation of optical properties of BB aerosols

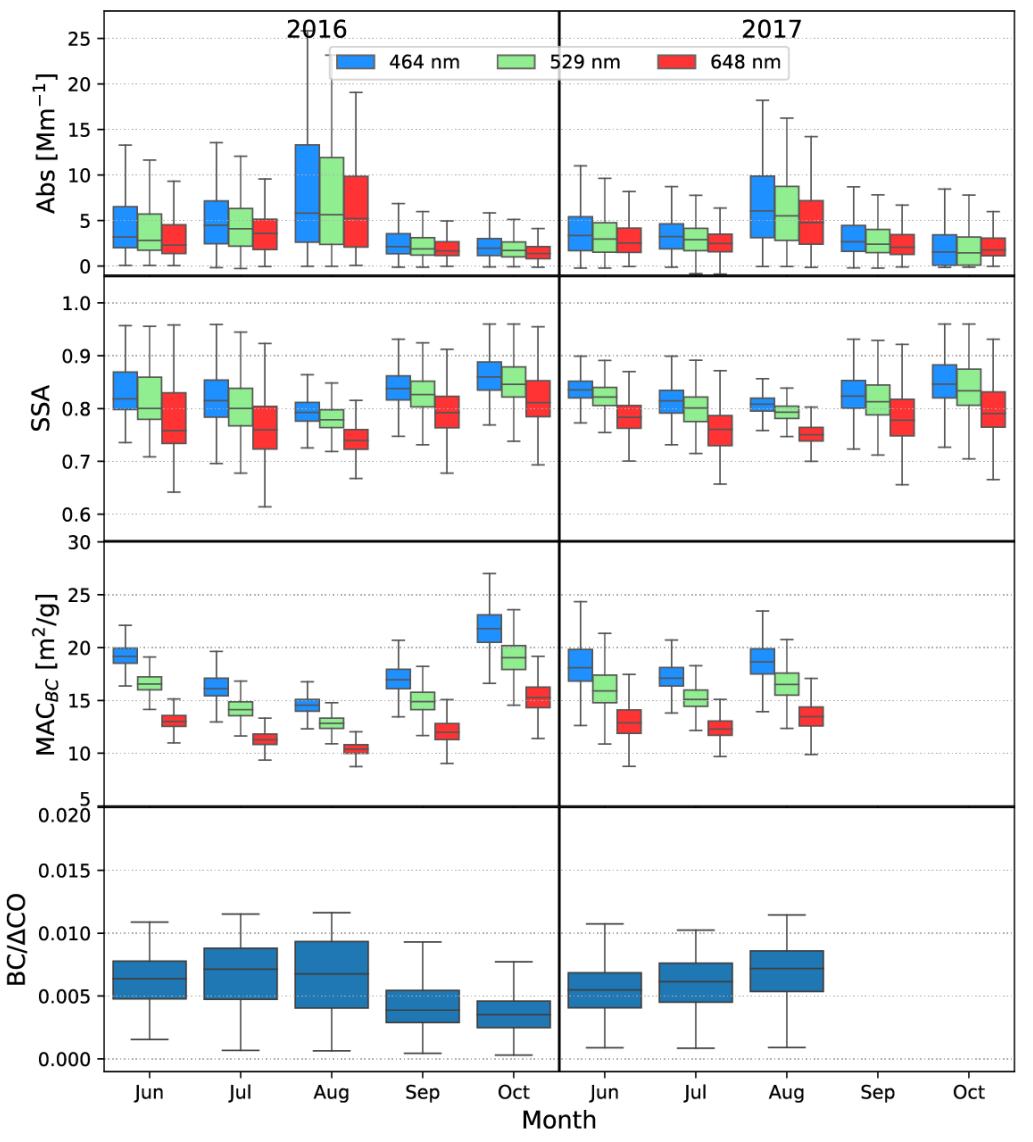

Figure 1. Monthly percentiles $(10 \%, 25 \%, 50 \%, 75 \%$, and $90 \%)$ of aerosol absorption coefficient, $\mathrm{SSA}, \mathrm{MAC} \mathrm{BC}$, and $\mathrm{BC} / \Delta \mathrm{CO}$ as box-whisker plots spanning the fire season in 2016 and 2017. The light blue, green and red colours of absorption, SSA, and $\mathrm{MAC}_{\mathrm{BC}}$ indicate observations at wavelengths of 464,529 , and $648 \mathrm{~nm}$, respectively. 
185 Zuidema et al. (2018) described the seasonal variation of SSA on ASI, and we also show this variation in Fig. 1 to facilitate illustration and comparison. SSA and absorption show opposite trends, i.e., from June-August, the aerosol absorption coefficient increases while SSA decreases, and from September to October, it shows the opposite variation. This indicates an increase in the proportion of absorbing aerosols from June to August, which leads to an increase in the aerosol absorption coefficient and a decrease in SSA, and a decrease in the proportion of absorbing aerosols from September to October. As BC

190 is the primary absorbing aerosol, this suggests a variable proportion of BC observed on the ASI during biomass burning, suggesting potential differences in BB plume for each month. The average SSA during the BB seasons is 0.81 at $529 \mathrm{~nm}$ wavelength, with the highest mean $\sim 0.85$ in October and the lowest $\sim 0.78$ in August. Such low values indicate the presence of pronounced absorption aerosol within the marine boundary layer in the south-eastern Atlantic. MACBC has a similar monthly pattern as SSA, which is particularly noticeable in 2016. This suggests that during the BB season, SSA and MACBC are lower

195 when the proportion of $\mathrm{BC}$ in the plume is higher, which can be explained by the change in the coating thickness of $\mathrm{BC}$ particles. As more $\mathrm{BC}$ aerosols are present in the plume, they compete for condensable material, resulting in a smaller average coating thickness on $\mathrm{BC}$ particles, leading to a decrease in SSA and $\mathrm{MAC}_{\mathrm{BC}}$. The mean MAC $\mathrm{BC}$ during the BB season in 2016 is 15.4 at $529 \mathrm{~nm}$, with the highest monthly mean values of 19.1 in October and the lowest of 12.9 in August.

The absorption enhancement Eabs is illustrated in Fig. 2. As Eabs is derived based on $\mathrm{MAC}_{\mathrm{BC}}$, it has the same trend as MACBC.

200 Eabs in 464 and $648 \mathrm{~nm}$ wavelength show large fluctuations when assuming the AAE of fresh uncoated BC in the range of 0.8 to 1.4; however, Eabs in the $529 \mathrm{~nm}$ is less sensitive to the AAE of fresh BC. Therefore, Eabs at $529 \mathrm{~nm}$ will be discussed and compared to observations from other geographical areas. The Eabs observed on ASI are higher than most of those observed in rural areas worldwide that are affected by BB (Xu et al., 2018), with some months averaging around 2.4. This finding is consistent with that of Denjean et al. (2020), which found that the absorption enhancement could reach $210 \%$ in the SEA. The 205 averaged Eabs at $529 \mathrm{~nm}$ wavelength are 1.96 in 2016 and 2.07 in 2017. Taylor et al. (2020) found an averaged Eabs around 1.85 around ASI, following the airborne measurements during CLARIFY, while they also showed the MAC $\mathrm{BC}_{\mathrm{BC}}$ is higher in the marine boundary layer than free troposphere, supporting our finding of such high Eabs on ASI. Zuidema et al. (2018) reported the July-September averaged MAC $\mathrm{BC}$ measured in 2016 on the ASI as 15.1, 13.3, and $10.7 \mathrm{~m}^{2} \mathrm{~g}^{-1}$ at 464, 529 and $648 \mathrm{~nm}$, which corresponds to Eabs as 1.70,1.71, and 1.68 respectively. The relatively low values they observed are due to the lower enhancement between July and September, with August having the lowest average of around 1.64 at three wavelengths. 


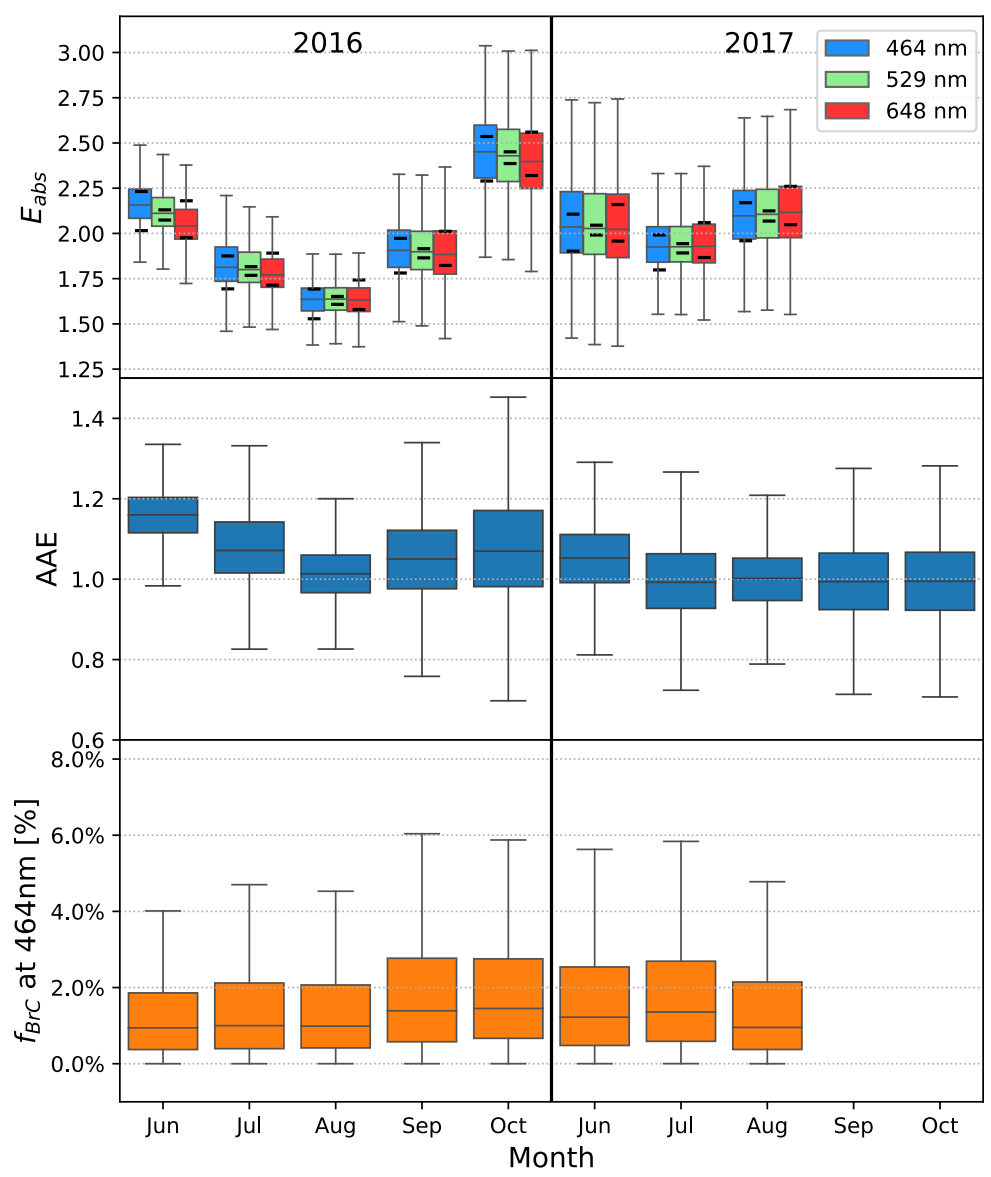

Figure 2. Monthly percentiles (10\%, 25\%, 50\%, 75\%, and 90\%) of absorption enhancement Eabs, AAE (between 464 and 648 $\mathrm{nm}$ ), and calculated $\mathrm{BrC}$ contribution to total absorption at $464 \mathrm{~nm}$ as box-whisker plots spanning the fire season in 2016 and 2017. $E_{a b s}$ is calculated by assuming an AAE of 1 for the fresh BC. The black solid lines in the upper panel indicate the upper and lower boundary of the calculated median $E_{a b s}$ when the AAE is in the range of 0.8 to 1.4.

The high value of $\mathrm{MAC}_{\mathrm{BC}}$ and $\mathrm{E}_{\mathrm{abs}}$ observed on $\mathrm{ASI}$ may be attributed by two factors: the high concentration of other absorbing aerosols, such as brown carbon $(\mathrm{BrC})$ and dust, or thickly coated $\mathrm{BC}$ particles. Fig. 2 shows the evaluated contribution from $\mathrm{BrC}$ on total absorption at $464 \mathrm{~nm}$ is generally around 1-2\%, suggesting $\mathrm{BrC}$ have a minimal influence on the ASI. Zhang et al. (2022) found around $\sim 10 \%$ of $\mathrm{BrC}$ at $470 \mathrm{~nm}$ near the African continent, while Taylor et al. (2020) found $\sim 10 \% \mathrm{BrC}$ at a much lower wavelength $(405 \mathrm{~nm})$ in the free troposphere near Ascension Island. In contrast to these measurements in the free troposphere, our observed BB plumes are generally considered to have experienced cloud processing, which could further reduce the $\mathrm{BrC}$ content (Che et al., 2022a). In addition to considering the contribution to absorption from BrC, Fig. 3 shows the plausible existence of dust particles (Fe bearing) as a contributor to the observed absorption, based on single-particle filter 
analysis by TEM-EDX (Dang et al., 2021) sampled close to ASI. Fe-bearing particles are suspected of contributing to this

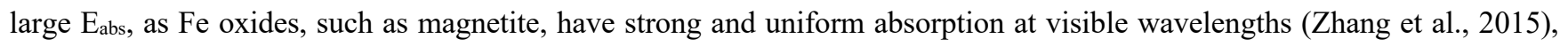
which could lead to a high $\mathrm{MAC}_{\mathrm{BC}}$, and an $\mathrm{AAE}$ around 1, consisting of our measured AAE (Fig. 2). However, only two samples were collected in the marine boundary layer near ASI, and only one sample includes aerosols from the BB, while the other shows clean sea salt aerosols. For the sample with BB aerosols, out of 50 sampled particles, 11 included Fe. Although this can prove the presence of Fe-bearing aerosols at ASI, the limitations of the sample numbers make it difficult to estimate 230 the proportion of Fe-bearing aerosols and whether they contribute significantly to the observed Eabs. Zhang et al. (2022) noticed a small contribution of Fe-bearing aerosols in the absorption based on an optical closure study with filter samples from the ORACLES aircraft campaign (ObseRvations of Aerosols above CLouds and their intEractionS) near the African continent. However, even considering a $10 \%$ absorption contribution is from dust, the upper limit, according to their conclusions, is still not enough to explain the high value of Eabs we observed on the ASI. Therefore, the high Eabs from ASI is most likely caused by the thickly coated BC particles, that is, the 'lensing effect', consisting with Denjean et al. (2020).
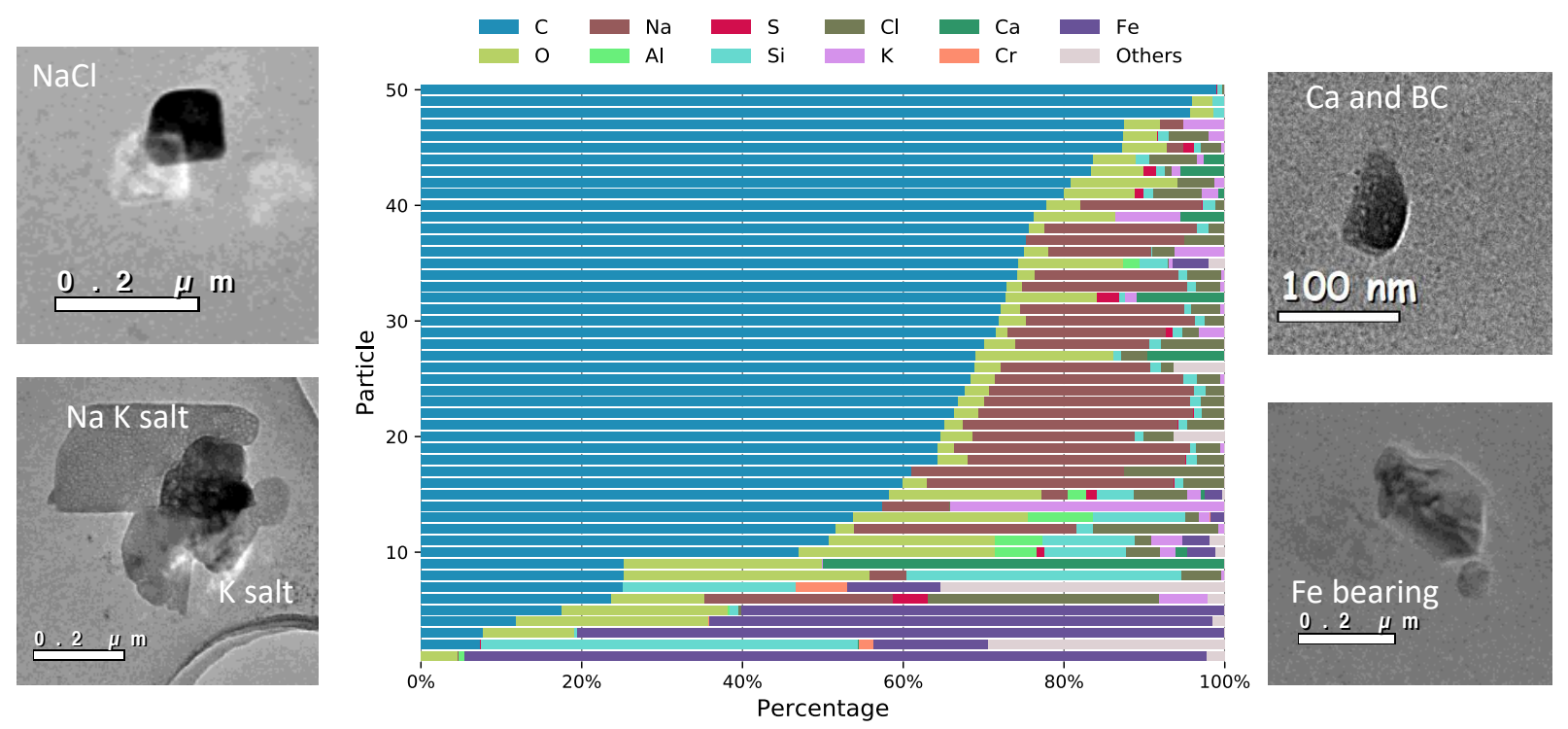

Figure 3. Elemental composition and representative microphysical images of particles from TEM-EDX analysis for the collected sample (sampled at 2017/08/24 9:43-9:49, at 319.4 m) near ASI.

240 After emission, $\mathrm{BC}$ particles can acquire additional coatings with age through deposition of semivolatile atmospheric species or coagulation with pre-existing particles, resulting in enhanced absorption of sunlight. As the African smoke engulfing ASI is aged for several days (Taylor et al., 2020), it is reasonable to expect the BC particles to have a thick coating. Previous studies 
have shown that BC particles encapsulated in a core-shell configuration display substantial Eabs (Adachi et al., 2010; Zhang et al., 2017), with values depending strongly on the ratio of coating materials to BC (Cappa et al., 2019; Peng et al., 2016; Liu et al., 2015; Xie et al., 2019; Cross et al., 2010). Chakrabarty and Heinson (2018) further proposed a power-law function to characterise the relation of $\mathrm{E}_{\mathrm{abs}}$ and mass ratio of coated particle to $\mathrm{BC}$ core $\left(\mathrm{M}_{\mathrm{tota}} / \mathrm{M}_{\mathrm{BC}}\right)$. By applying this relation to our data, we estimate the average $\mathrm{M}_{\mathrm{total}} / \mathrm{M}_{\mathrm{BC}}$ of $\sim 7.5$ in 2016 and $~ 8.8$ in 2017 during the BB season, suggesting that, on average, the mass of coated materials is $\sim 6.5$ and $\sim 7.8$ times higher than BC cores during in those two years. Zhang et al. (2017) theoretically investigated the effect of $\mathrm{BC}$ microphysical properties on Eabs using the multiple-sphere T-matrix method. According to their results, we estimate the ratio of the shell-core ratio (spherical equivalent particle diameter divided by $\mathrm{BC}$ core diameter) is 2.2 on average, suggesting that the coating thickness is 1.2 times the $\mathrm{BC}$ core radius.

In addition to thick coating, there are other factors that can result in high $\mathrm{E}_{\mathrm{abs}}$, such as the particle morphology (i.e., the physical arrangement of $\mathrm{BC}$ with respect to other components within a given particle) and different refractive index of $\mathrm{BC}$ (Zhang et al., 2017). If the particle has an off-centre core-shell structure (BC core is partially encapsulated or attached to the edge of its shell), then the Eabs would be small or close to 1, suggesting the ageing has a minimal effect on absorption with such structure (Cappa et al., 2019). Furthermore, with the increase of the shell-core ratio, the Eabs even decrease for those off-centre coreshell particles (Zhang et al., 2017). While for particles with concentric core-shell structures (BC core located at coating centre), Eabs increases substantially with the coating thickness. Therefore, our results may suggest most of the BC particles on ASI have concentric core-shell structures. The higher refractive index of BC can also lead to larger calculated Eabs, which may be another reason behind the high $\mathrm{E}_{\mathrm{abs}}$ observed on the ASI. However, the impact of the refractive index on Eabs is relatively small and within $4 \%$ (Zhang et al., 2017). Therefore, we speculate that most of the BC aerosols observed on the ASI have a very thick coating and are concentrically structured, consistent with the finding from CLARIFY aircraft observation (Taylor et al., 2016). As most climate models use a fixed value of Eabs $\sim 1.5$ (Wang et al., 2014), our results suggest that the absorption in the southeastern Atlantic may be significantly underestimated.

\section{2 $\mathrm{BC} / \Delta \mathrm{CO}$ and aerosol optical properties}

The lowest panel in Fig. 1 shows the monthly variation of the enhanced ratio of $\mathrm{BC}$ to $\mathrm{CO}(\mathrm{BC} / \triangle \mathrm{CO}$, detailed in methods). $\mathrm{BC} / \triangle \mathrm{CO}$ increases from June to August and decreases in the following two months in both 2016 and 2017, showing an opposite trend to that of SSA, MAC $\mathrm{BC}_{\mathrm{BC}}$, and even $\mathrm{AAE}$ and $\mathrm{E}_{\mathrm{abs}}$ in Fig. 2. As BC/ $\triangle \mathrm{CO}$ can indicate the emission conditions near the fire source, this finding may suggest the seasonal variation of aerosol properties observed on ASI may be driven by the burning conditions of African fires. However, as ASI is several days away from the burning locations in terms of the plume transport, atmospheric ageing can also affect the observed $\mathrm{BC} / \Delta \mathrm{CO}$. A more detailed analysis of $\mathrm{BC} / \Delta \mathrm{CO}$ and factors behind its variation is presented in the following section. Here we investigate in detail the relationship between $\mathrm{BC} / \triangle \mathrm{CO}$ and $\mathrm{BB}$ aerosol optical properties shown in Fig. 1. 

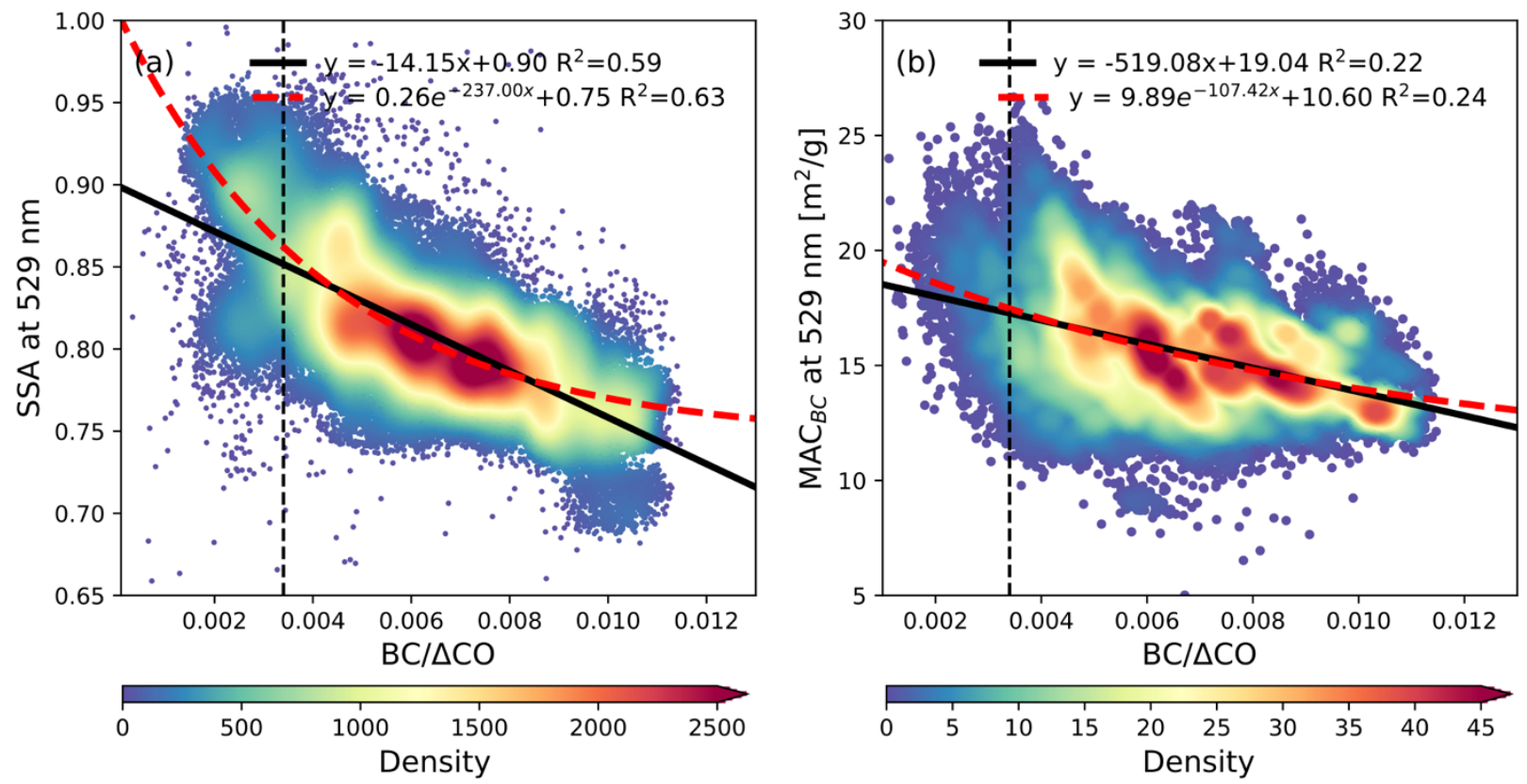

Figure 4. Relations of $\mathrm{BC} / \triangle \mathrm{CO}$ with (a) SSA and (b) $\mathrm{MAC} B \mathrm{BC}$ at $529 \mathrm{~nm}$ wavelength. The solid black lines represent the linear regressions, and the red dash lines are the curves fitting with the function displayed in the legend. The colour scale indicates the density of the data in each plot. The vertical dashed black lines in each plot corresponding to $\mathrm{BC} / \Delta \mathrm{CO}=0.0034$

The relationship between $\mathrm{BC} / \triangle \mathrm{CO}$ and $\mathrm{SSA}$ and $\mathrm{MAC}_{\mathrm{BC}}$ at $529 \mathrm{~nm}$ wavelength are exhibited in Fig. 4, where the colour scale indicates the density of the data. Overall, there is a tendency for both SSA and $\mathrm{MAC}_{\mathrm{BC}}$ to decrease with the increase in $\mathrm{BC} / \Delta \mathrm{CO}$. The decrease of SSA with $\mathrm{BC} / \Delta \mathrm{CO}$ is more dramatic when $\mathrm{BC} / \Delta \mathrm{CO}$ is smaller than 0.0034 (left side of the black dashed line). Since higher $\mathrm{BC} / \triangle \mathrm{CO}$ represents a larger fraction of $\mathrm{BC}$ emitted from the combustion (which suggests that combustion becomes more flaming), the trend of decreasing SSA and $\mathrm{MAC}_{\mathrm{BC}}$ with increasing $\mathrm{BC} / \triangle \mathrm{CO}$ indicates that a higher fraction of flaming combustion can result in a lower SSA and $\mathrm{MAC}_{\mathrm{BC}}$. This may be due to flaming fires producing more $\mathrm{BC}$ particles, which can directly lower the SSA. In contrast, smouldering combustion is characterised by a higher concentration of scattering OA, therefore, a higher SSA. The magnitude of the $\mathrm{MAC}_{\mathrm{BC}}$ depends mainly on the shell-core ratio of $\mathrm{BB}$ aerosols, as discussed in the previous section. Microscopy observations have suggested that smouldering dominated combustion can result in a smaller BC core and thicker coating (Adler et al., 2010; Wang et al., 2017), as smouldering combustion has higher gas-phase organic compound emissions (Yokelson et al., 2009), and can result in a higher SOA formation ratio (Vakkari et al., 2018). Consequently, the shell-core ratio of $\mathrm{BC}$ particles is higher in smouldering fires, leading to a higher MAC $\mathrm{BC}_{\mathrm{BC}}$ While for the flaming fires, a higher number of $\mathrm{BC}$ particles compete for coating materials, resulting in a reduction in the average coating thickness on $\mathrm{BC}$ aerosol, and thus a reduction in $\mathrm{MAC}_{\mathrm{BC}}$. 
In Fig. 4, SSA and $\mathrm{MAC}_{\mathrm{BC}}$ are approximated by linear and exponential functions with $\mathrm{BC} / \Delta \mathrm{CO}$, respectively (black and red fitting lines). Despite the scattered SSA and $\mathrm{MAC}_{\mathrm{BC}}$ values, the fitted lines are able to well represent the denser data. The exponential function can represent the relationship between SSA and $\mathrm{BC} / \triangle \mathrm{CO}$ better than the linear regression with a higher $\mathrm{R}^{2}$ value, especially when $\mathrm{BC} / \Delta \mathrm{CO}<0.0034$, where a rapid increase of SSA is observed as $\mathrm{BC} / \Delta \mathrm{CO}$ decreases. However, $\mathrm{MAC}_{\mathrm{BC}}$ values are highly scattered when $\mathrm{BC} / \triangle \mathrm{CO}$ is small (less than 0.04 ), so for $\mathrm{MAC}_{\mathrm{BC}}$, the differences in linearity and curve fittings are not significant. The scatter of $\mathrm{MAC}_{\mathrm{BC}}$ is mainly related to the $\mathrm{BC}$ measurements, as $\mathrm{MAC} \mathrm{C}_{\mathrm{BC}}$ calculated from the absorption and $\mathrm{BC}$ mass ratio has a large uncertainty when the $\mathrm{BC}$ content is small. Nevertheless, these functions provide us with a simple way to estimate the parameters of the aerosol optical characteristics in the south-eastern Atlantic, and can help to improve the parameterisations used in climate models.

\section{Discussion}

Since $\mathrm{BC} / \triangle \mathrm{CO}$ shows a good linear relationship with the optical properties of aerosols observed on ASI, factors that affect the value of $\mathrm{BC} / \triangle \mathrm{CO}$ are examined in this section. The potential drivers of the variation of aerosol optical properties during $\mathrm{BB}$ season are also discussed. The magnitude of $\mathrm{BC} / \Delta \mathrm{CO}$ depends primarily on two factors, one being the condition of the combustion, and the other being the scavenging of aerosols during transport of the plume. Here we discuss the relation of $\mathrm{BC} / \Delta \mathrm{CO}$ and burning conditions in 4.1 , and explore the reasons behind the monthly variation of $\mathrm{BC} / \Delta \mathrm{CO}$ in 4.2 and 4.3 . In 4.2 , we mainly discuss the variation in aerosol scavenging, and in 4.3 , we focus on the burning conditions and the factors behind its monthly variation.

\section{1 $\mathrm{BC} / \Delta \mathrm{CO}$ and burning conditions}

310 As discussed earlier, $\mathrm{BC} / \Delta \mathrm{CO}$ is related to the combustion conditions of the fire. The combustion phase of biomass, i.e., flaming, smouldering, and pyrolysis, is commonly represented by the modified combustion efficiency (MCE). Higher MCE indicates a larger fraction of flaming combustion, and when MCE equals 0.9 , it means that the combustion is about half flaming and half smouldering (Akagi et al., 2011). However, the calculation of the MCE requires the determination of the background concentrations of $\mathrm{CO}$ and $\mathrm{CO}_{2}$, which will introduce uncertainties, especially in aged plumes. $\mathrm{BC} / \Delta \mathrm{CO}$ can also represent the

315 burning condition, and was proved more reliable than MCE for combustion characterization in diluted plumes by Vakkari et al. (2018), who investigated the secondary organic formation in Africa aged plumes. 


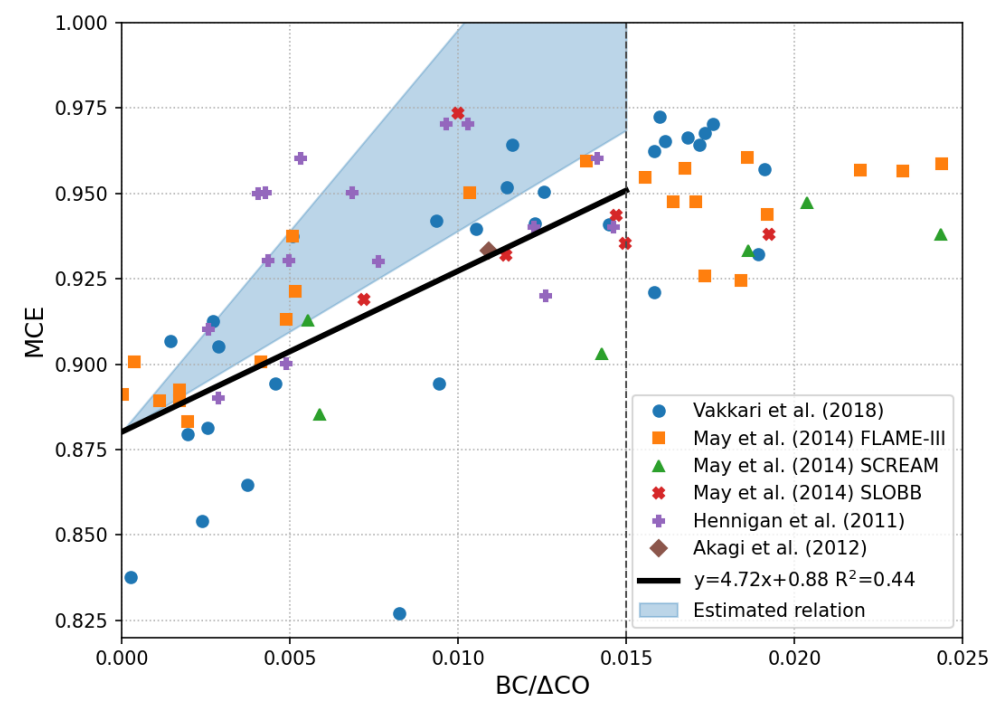

Figure 5. Summary of $\mathrm{BC} / \triangle \mathrm{CO}$ and the corresponding modified combustion efficiency (MCE) from literature for fresh fires (age $<0.5 \mathrm{~h}$ ). The solid black line is the linear regression of $\mathrm{BC} / \triangle \mathrm{CO}$ and $\mathrm{MCE}$ values from various investigations (Hennigan et al., 2011; May et al., 2014; Vakkari et al., 2018; Akagi et al., 2012) for $\mathrm{BC} / \Delta \mathrm{CO}<0.015$, and the blue shaded areas indicate the estimated zones for BB aerosol with cloud processing.

The relationship between $\mathrm{MCE}$ and $\mathrm{BC} / \triangle \mathrm{CO}$ is clearer for fresh plume (Vakkari et al., 2018). Fig. 5 shows the relation of $\mathrm{MCE}$ and $\mathrm{BC} / \triangle \mathrm{CO}$ for near-source $\mathrm{BB}$ plume $(\mathrm{age}<0.5 \mathrm{~h})$ from the literature. From the figure, it is shown that MCE increases with $\mathrm{BC} / \triangle \mathrm{CO}$, indicating that the higher $\mathrm{BC} / \Delta \mathrm{CO}$ represents the higher fraction of flaming combustion. However, the relationship between $\mathrm{BC} / \triangle \mathrm{CO}$ and MAC is not linear across the entire range, as suggested by May et al. (2014), where the growth of MAC becomes much slower for $\mathrm{BC} / \Delta \mathrm{CO}$ greater than 0.015. Vakkari et al. (2018) found that when $\mathrm{BC} / \Delta \mathrm{CO}$ is smaller than 0.015 , MCE shows a clear near-linear relation with the $\mathrm{BC} / \Delta \mathrm{CO}$. Therefore, in the figure, we fitted (black solid line) the available observational data for $\mathrm{BC} / \Delta \mathrm{CO}$ values less than 0.015 . The result shows a reasonable linear relationship of $\mathrm{MCE}$ and $\mathrm{BC} / \triangle \mathrm{CO}$, with the $\mathrm{R}^{2}$ value $=0.44$. Therefore, this result suggests that with the increasing fraction of flaming combustion, $\mathrm{BC} / \triangle \mathrm{CO}$ also increases. Our measured $\mathrm{BC} / \Delta \mathrm{CO}$ values are generally smaller than 0.012 , suggesting this linear relation is applicable to our data. This linear relationship, therefore, suggests that one of the major factors contributing to the variation in the observed $\mathrm{BC} / \triangle \mathrm{CO}$ is the change in combustion state from the $\mathrm{BB}$ region. Based on this fitted line, we estimate that $\mathrm{BC} / \Delta \mathrm{CO}$ is around 0.004 when $\mathrm{MCE}=0.9$. This means for fresh plume with $\mathrm{BC} / \Delta \mathrm{CO}>0.004$, the burning is dominated by flaming combustion, while when $\mathrm{BC} / \Delta \mathrm{CO}<0.004$, the burning is mainly smouldering. Considering that the plume reaching 335 ASI undergoes atmospheric ageing and scavenging processes of about one week, for a plume from the same burning, the value of $\mathrm{BC} / \triangle \mathrm{CO}$ we observed should be lower than the fresh ones. Therefore, our observed $\mathrm{BC} / \Delta \mathrm{CO}$ corresponding to $\mathrm{MCE}=0.9$ 
should be less than 0.004. Owing to the absence of $\mathrm{CO}_{2}$ observations on the ASI, we are unable to directly compare the $\mathrm{BC} / \triangle \mathrm{CO}$ observed with $\mathrm{MCE}$; however, when $\mathrm{BC} / \Delta \mathrm{CO}>0.004$, the plume is likely to be all from the flaming combustion.

Since BB aerosols are transported above clouds, the BB aerosols observed on the ASI may have undergone cloud removal as they enter the boundary layer. In a previous study (Che et al., 2022a), we have found that cloud processing is responsible for $\sim 20$ to $\sim 80 \%$ of the reduction of aerosol mass with the transport of the plume from the African continent, depending on the cloud liquid content and the residence time of the BB aerosol in the cloud layer. Assuming that all $\mathrm{BB}$ aerosols observed on the ASI undergo cloud processing and assuming that the cloud processing removes 20 to 80 percent of the aerosols, then the linear relationship for our observed $\mathrm{MCE}$ and $\mathrm{BC} / \triangle \mathrm{CO}$ would lie in the blue shaded interval in Fig. 5 (a). The upper and lower 345 boundaries of the shaded area represent the relationship between $\mathrm{BC} / \Delta \mathrm{CO}$ and $\mathrm{MCE}$ for 20 and $80 \%$ of aerosol removal, respectively. As a result, our observed $\mathrm{BC} / \Delta \mathrm{CO}$ corresponding to an $\mathrm{MCE}$ equal to 0.9 ranges from 0.0017 to 0.0034 . This finding is consistent with the relationship between $\mathrm{BC} / \mathrm{CO}$ and $\mathrm{SSA}$, i.e., the rate at which $\mathrm{SSA}$ decreases with $\mathrm{BC} / \Delta \mathrm{CO}$ changes clearly for $\mathrm{BC} / \triangle \mathrm{CO}$ around 0.0034 (the black dashed line), potentially indicating a shift in combustion state, i.e., from smouldering to flaming. However, the estimated value of our measured $\mathrm{BC} / \Delta \mathrm{CO}$ corresponding to an $\mathrm{MCE}$ of 0.9 has large uncertainties. Our assumption is that all BB aerosols undergo cloud removals, but in reality, there will be BB aerosols that do not pass through the clouds, as the cloud cover is not $100 \%$, in which case the $\mathrm{BC} / \Delta \mathrm{CO}$ value corresponding to $\mathrm{MCE}=0.9$ will be higher than our estimated values, but should not exceed 0.004. However, with regard to the linear relationship between $\mathrm{BC} / \triangle \mathrm{CO}$ and $\mathrm{MCE}$, the reason for the seasonal variation in $\mathrm{BC} / \Delta \mathrm{CO}$ as shown in Fig. 1 may be that there is a change in combustion conditions in each month, i.e., from June to August there is an increase in the proportion of flaming combustion,

355 while from September to October smouldering combustion increases. This finding is consistent with Fig. S3, which shows that burning with higher fire radiative power (FRP) declined in September and October. 


\subsection{Aerosol scavenging}
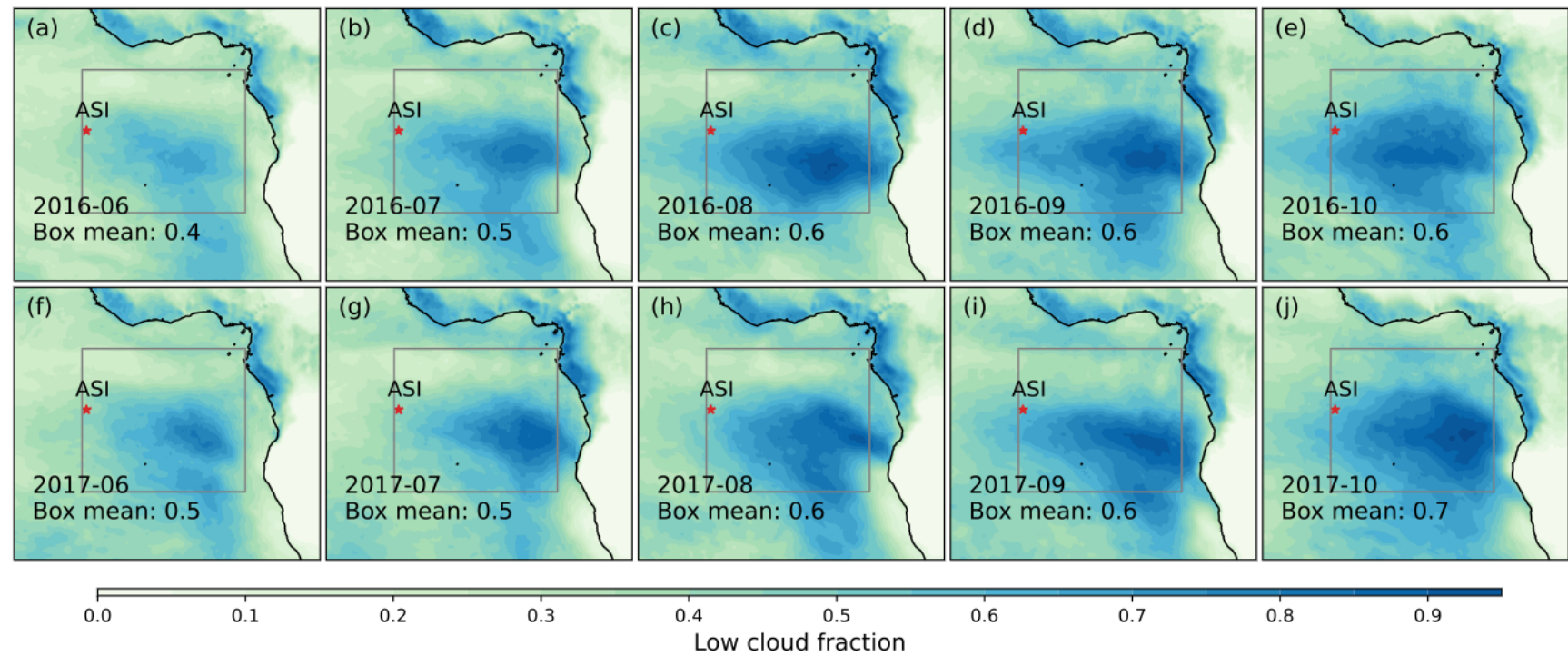

Figure 6. Monthly mean low cloud fraction calculated from the ERA5 reanalysis data. The location of ASI is marked as the

red star. The grey boxes represent the range of the main transport paths of BB aerosols observed on ASI. The box means are the mean cloud fractions calculated in the grey box region.

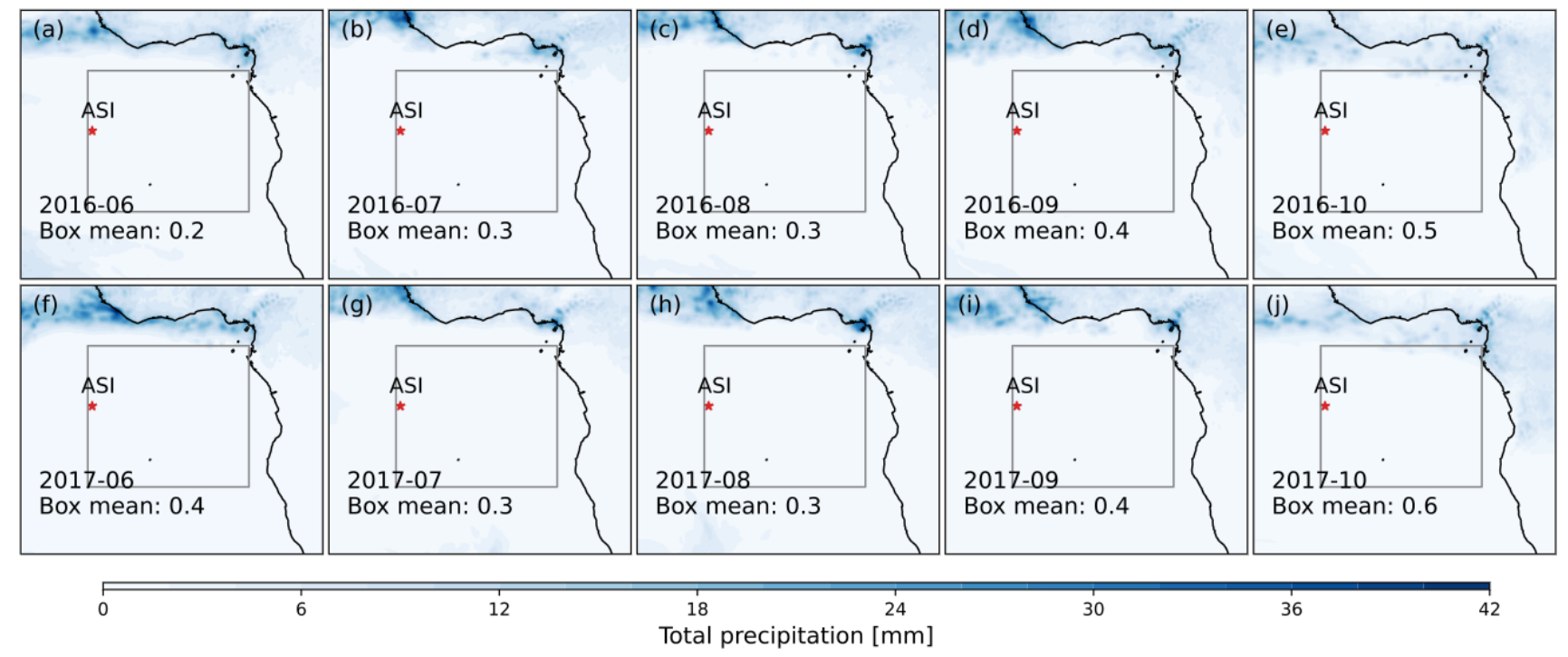

Figure 7. Same with Fig 6, but with precipitation.

Cloud processing and rain removal are the two main mechanisms for BB aerosol scavenging (Textor et al., 2006). The monthly variation of the mean low-level cloud fraction and precipitation are illustrated in Fig. 6 and 7. Using the location of ASI as a 
boundary, we placed a box at the upstream areas of the plume to roughly represent the main paths and areas of the plume transport, which are indicated by a grey box in both figures. The position of this box is approximately consistent with the backward trajectories of the plume (Fig S2). The mean value inside the box is calculated to roughly to represent the average cloud cover and precipitation during the transport of the plume.

370 From Fig. 6, it can be seen that in the plume transport region, the proportion of low clouds increases from June to August, indicating the increase of the probability of aerosols undergoing cloud processing, which could result in a decrease in $\mathrm{BC} / \Delta \mathrm{CO}$ from June to August. Mean precipitation in the grey box remains almost constant from June to August (Fig 7), indicating that the contribution of rain removal mechanisms to the $\mathrm{BC} / \Delta \mathrm{CO}$ did not change during these months. Thus, aerosol scavenging should negatively affect $\mathrm{BC} / \Delta \mathrm{CO}$ from June to August, which is inconsistent with the observed increase in $\mathrm{BC} / \Delta \mathrm{CO}$, suggesting that changes in combustion status may be the main reason for the increase in $\mathrm{BC} / \Delta \mathrm{CO}$ during these months. From August to October, the mean proportion of cloud cover within the grey box generally remained the same, suggesting that cloud processes may not have had much influence on the change in $\mathrm{BC} / \Delta \mathrm{CO}$ from August to October. However, the mean precipitation in the grey box increases from August to October, suggesting the potential increase of the rain removal of BB aerosols in these months, which can result in a decrease of $\mathrm{BC} / \Delta \mathrm{CO}$, consistent with our observations. In general, the increase in $\mathrm{BC} / \Delta \mathrm{CO}$ from June to August is probably mainly due to changes in combustion conditions, and the effect of aerosol scavenging may not be significant. In contrast, from August to October, rain removal of BB aerosols may have increased, which may, in turn, have contributed to the reduction in $\mathrm{BC} / \Delta \mathrm{CO}$ during that period.

\subsection{Changes in BB burning conditions}

\subsubsection{Changes in BB burning location and fuel types}

385 The variation of burning location on the African continent is illustrated in the supplement (Fig. S4). In the 2016 and 2017 BB seasons, there is also no significant change in biomass burning locations for the same months, and the number of fires is similar. Therefore, we further compare the changes in fuel sources in different months using 2016 as an example, as shown in Fig. 8. The major burning sites in different months are defined as areas with a cumulative number of fires $>500$ for that month, and are illustrated in the black contour in the figure. In general, the main burning areas shift eastwards from June to October in 2016 and 2017. From June to August, the main burning areas gradually expanded. In contrast, the smallest burning areas are found in September and October, mainly in south-eastern Africa. For the fuel source, the results indicate that savannah burning is predominant in each month, while the proportion of burning in grasses/cereal is higher in September and October. Especially during October, major burning also occurs in the northern grassland areas. Different burning fuels may result in changes in combustion conditions, but their effect is uncertain. The increased burning in grasses/cereal areas may suggest a

395 source of fuel dependence on the observed decrease in $\mathrm{BC} / \Delta \mathrm{CO}$ in September and October. $\mathrm{BC} / \Delta \mathrm{CO}$ is increasing from June to August, but there is no significant change from the fuel source, which imply that the change in combustion conditions during 
https://doi.org/10.5194/acp-2022-160

Atmospheric

Chemistry

(c) Author(s) 2022 CC BY 4.0 License.

and Physics

Discussions

these periods is not caused by changes in fuel sources. However, more detailed studies will be required to further investigate the relation between fuel source and $\Delta \mathrm{BC} / \Delta \mathrm{CO}$ ratio, especially for the seasonal dependence.
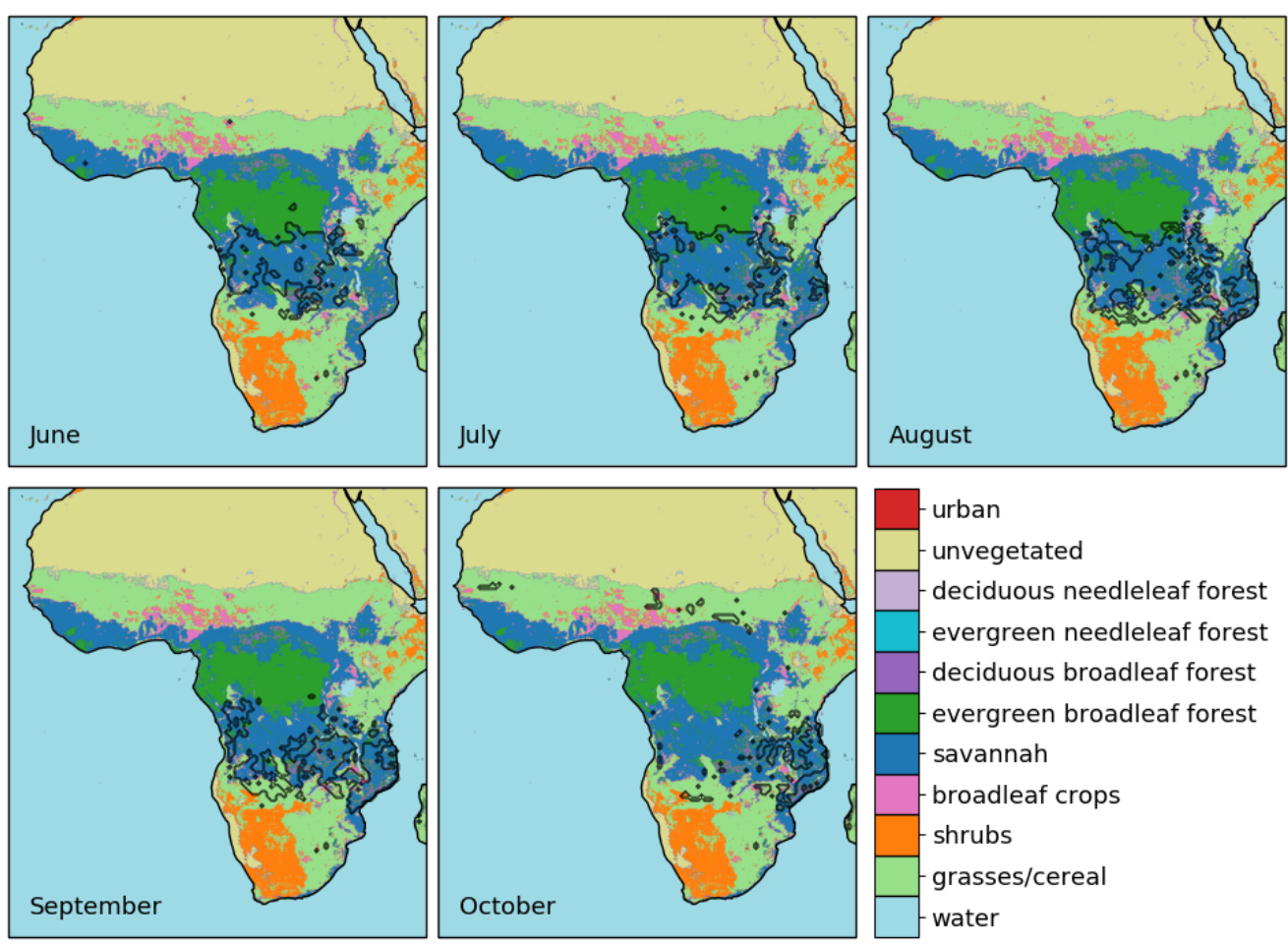

Figure 8. Major burning locations and land covers during the BB season in 2016. The different colours on the land indicate different land types. Areas with accumulated fire count greater than 500 are illustrated in the black contour each month. The land cover data is from the MODIS collection 6 product MCD12Q1 (https://doi.org/10.5067/MODIS/MCD12Q1.006) 

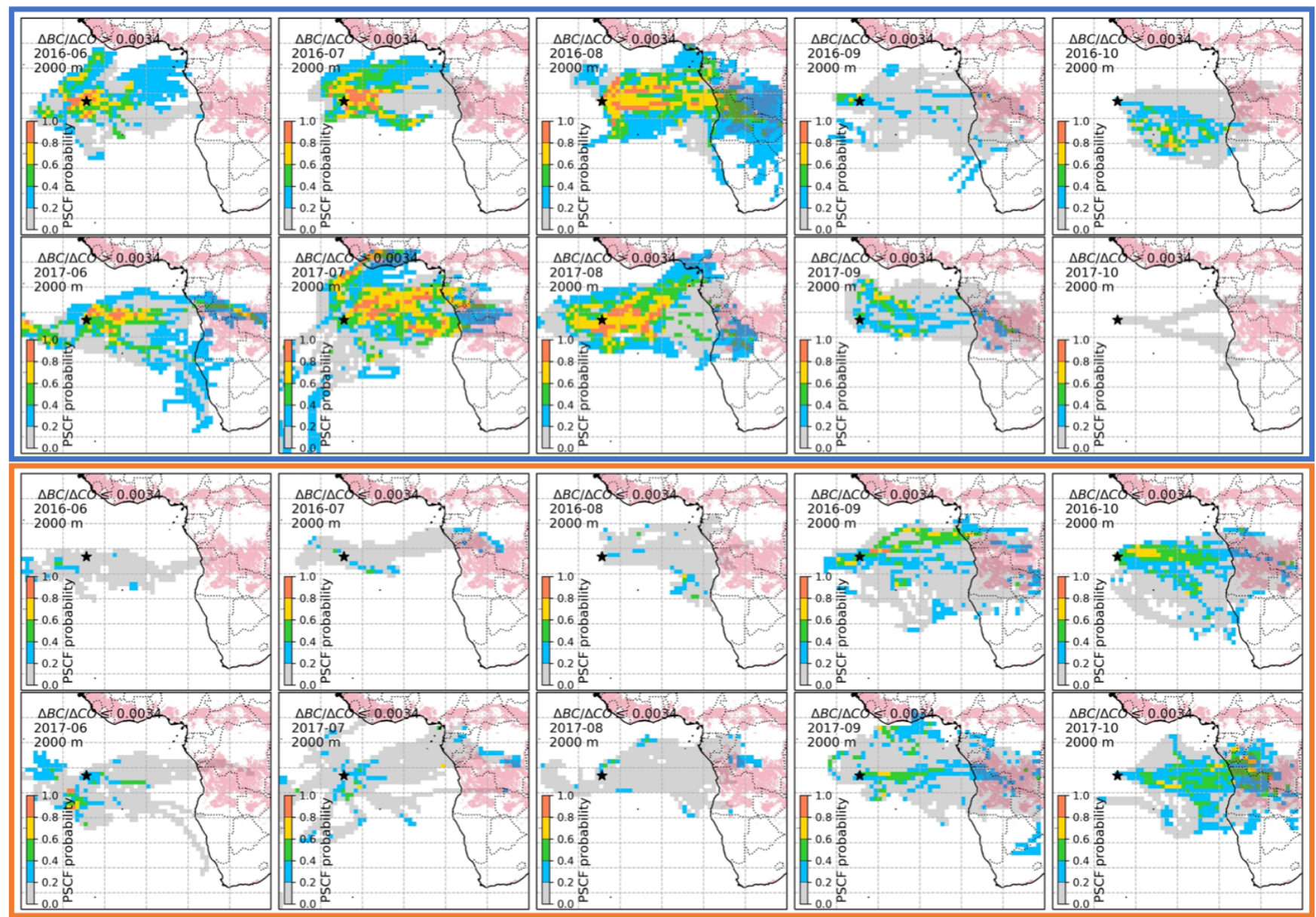

Figure 9. The spatial distribution of potential source contribution function (PSCF) during the Africa fire season in 2016 and 2017. The 7-day backward trajectories in the upper blue and lower orange rectangles indicate air mass flow when $\mathrm{BC} / \Delta \mathrm{CO}>$ or $\leq 0.0034$, respectively. Different colours indicate the probability of different transport paths of the plumes. Note the trajectories are initiated at an altitude of $2000 \mathrm{~m}$ at the sampling site (marked as the black star) on ASI. The pink areas on the continent indicate savannah, the main burning material in each month.

The PSCF results derived from the 7-day backward trajectories initiated at an altitude of $2000 \mathrm{~m}$ at the sampling site during the African fire seasons are illustrated in Fig. 9. These trajectories represent the transport of air masses in the free troposphere. A similar analysis but for trajectories initiated at an altitude of $500 \mathrm{~m}$ is shown in the supplement Fig. S5. Those boundary 415 layer airflow generally exhibit a similar pattern for different months, i.e., southeasterlies advecting clean Southern Hemisphere 
air around the southern Atlantic subtropical anticyclone, as illustrated by Zuidema et al. (2018). Those findings suggest the BB aerosols observed on ASI mainly result from the entrainment of the free troposphere plumes. Therefore, back trajectories in the free troposphere are more relevant for the indication of the BB geographical source fuel.

The trajectories and main pathway of the airmass for $\mathrm{BC} / \Delta \mathrm{CO}>0.0034$ cases, representing potential flaming combustions, are illustrated inside the upper blue rectangle for each month. In contrast, the lower orange rectangle shows the trajectories of airmass for potential smouldering dominated combustions with $\mathrm{BC} / \Delta \mathrm{CO} \leq 0.0034$. Overall, the air mass trajectories do not vary much in the direction from month to month for different $\mathrm{BC} / \Delta \mathrm{CO}$ values, although a stronger zonal wind in October was documented (Zhang and Zuidema, 2021). For those observations where $\mathrm{BC} / \Delta \mathrm{CO}>0.0034$ (flaming conditions), back trajectories suggest BB aerosols originated from the savannah increases from June to August. Moreover, trajectories with high $\mathrm{BC} / \triangle \mathrm{CO}$ values during August have a higher probability of originating from the savannah, while the trajectories with small $\mathrm{BC} / \triangle \mathrm{CO}$ are more likely to originate from other sources. This may indicate that the difference in fuel source contributes to the change in combustion conditions and result in a change in $\mathrm{BC} / \Delta \mathrm{CO}$. During September and October, the probability of trajectories from the savannah but with smaller $\mathrm{BC} / \Delta \mathrm{CO}$ increases, suggesting that savannah burning became more smouldering during these months. In contrast, savannah burning is dominated by flaming combustion in August. This difference may be attributed to the change in meteorological conditions and water content in the fuel.

\subsubsection{Variation of normalized difference moisture index}

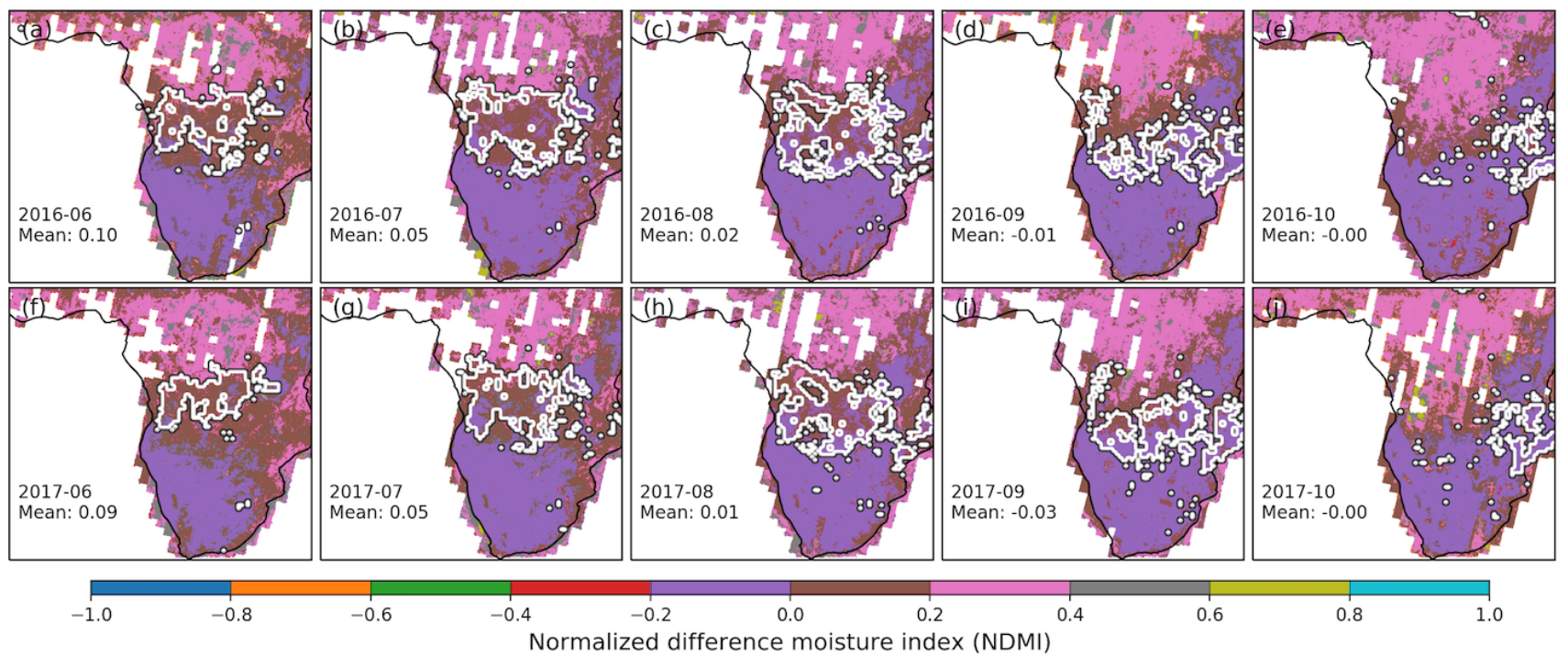

Figure 10. Major burning locations and normalized difference moisture index (NDMI) during the BB season in 2016 and 2017. Areas with accumulated fire count greater than 500 are illustrated in the black contour in each month, and are defined as the major burning areas. The mean values of NDMI in the major burning areas each month are also displayed in the figure. 
The NDMI (Normalized Difference Moisture Index) is used to describe the water stress level in vegetation, and can be used to monitor fuel levels in fire-prone areas. The monthly mean NDMI within the major bunning areas are labelled in the figure. As can be seen, mean NDMI in the major burning areas decreases from June to August, indicating the fuel become drier. The primary fuel from June to August is Savannah and without significant change, therefore the change in burning state is likely to be a result of changes in the water content of the fuel. When the fuel is drier, the more flaming of the combustion. This result is consistent with the increase in $\mathrm{BC} / \Delta \mathrm{CO}$ in these months, suggesting that it is likely that the burning became more flaming from June to August is caused by the drier of the fuel. The average NDMI for both September and October are smaller than that of August, suggesting that fuel is drier in these two months. However, $\mathrm{BC} / \Delta \mathrm{CO}$ are lower in September and October than in August, meaning that the change in moisture in the fuel is not the main reason for the decrease in $\mathrm{BC} / \Delta \mathrm{CO}$ between these two months. Although the average NDMI in the main burning areas is lower than that in other months, the value of NDMI increases slightly from September to October and is more noticeable in 2017. This indicates an increase in fuel water content in October compared to September, consistent with the observed decrease in $\mathrm{BC} / \Delta \mathrm{CO}$. However, as changes in combustion conditions do not depend solely on the water content of the fuel, factors such as surface wind can also have an effect, therefore the change in September/October may also be related to other factors.

\subsubsection{Impact of meteorological factors on combustion conditions}

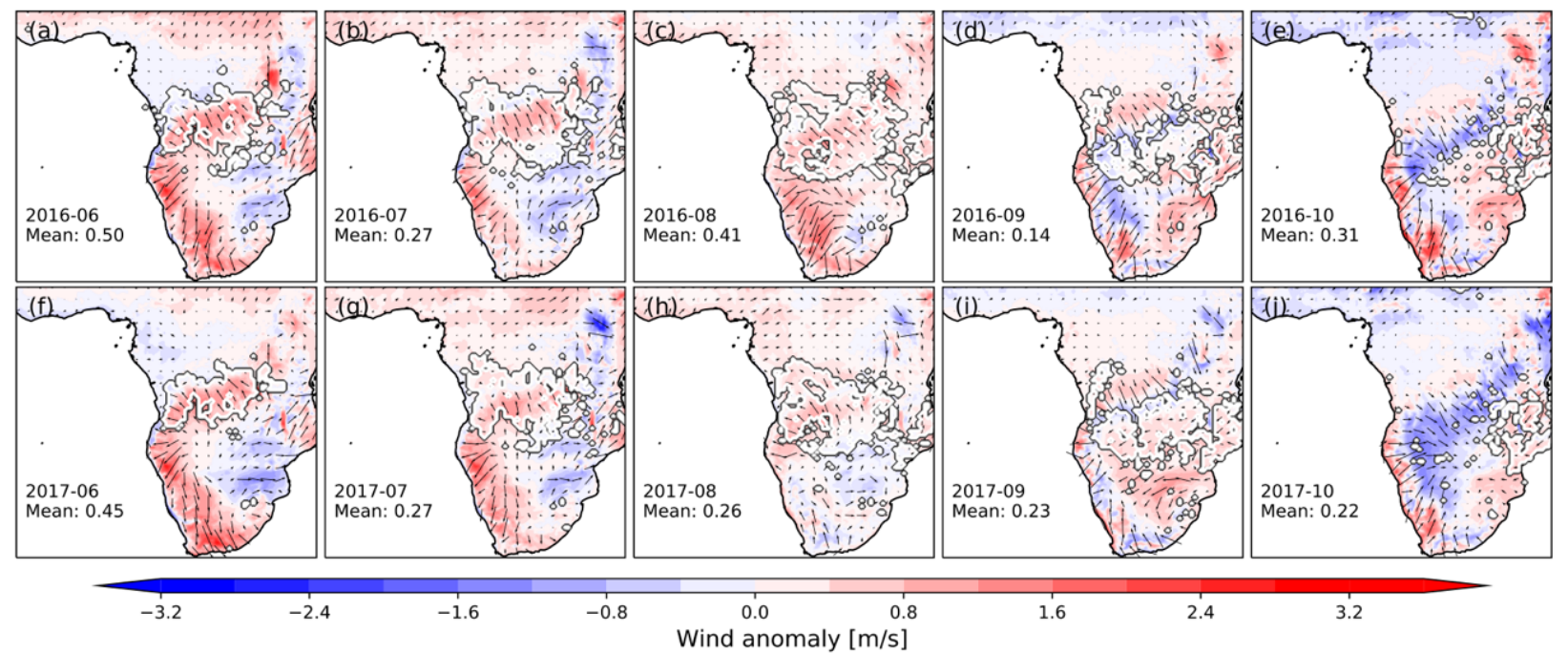

Figure 11. Monthly-mean surface wind anomaly calculated from the ERA5 reanalysis data. The baseline is an average from June to October in 2016 and 2017 combined. The means are calculated as the average anomalies in the major burning areas (> 500 fire counts), which is illustrated in the black counter each month. 
455 The current understanding of the mechanisms leading to the changes and transition between smouldering and flaming combustions is poor and mostly limited to experiments (Santoso et al., 2019). In general, previous studies have suggested that wind can exert competing effects; first by increasing the oxygen supply, which will increase the flaming combustion fraction, and second, by simultaneously increasing the effective cooling, thereby suppressing active flaming. The surface wind anomalies in each month during the BB season in 2016 and 2017 are shown in Fig. 11. A distinctive feature is the noticeable lower wind speeds in September and October in the main burning areas. This result may suggest the decrease in wind speed may have led to a reduction in oxygen supply, resulting in the increase of the proportion of smouldering combustion in September and October. Another feature is the change in the direction of the wind during these months. From June to August, a relatively large proportion of winds from the southeast allowed the burning to expand northwards. In September and October, however, the northwest winds begin to increase, causing the burning area to return to the south where it had previously burned and move eastwards. The airflow during September and October are proposing smouldering propagations, which may carry the heat away from the burning zone away to the ash layer, diminishing the heat supplied for heating the fuel and resulting in an increased fraction of smouldering combustion (Santoso et al., 2019).

\section{Conclusion}

A 17-month in-situ campaign was conducted on ASI during 2016-2017. The monthly variation of measured aerosol optical properties during the African BB seasons are investigated in this paper. An increase of aerosol absorption coefficient from June to August is observed along with a concomitant reduction in SSA and $\mathrm{MAC}_{\mathrm{BC}}$. In contrast, during September and October, the aerosol absorption coefficient decreases, with the increases in SSA and $\mathrm{MAC}_{\mathrm{BC}}$. The highest SSA is observed in October, with a mean value $\sim 0.85$ at $529 \mathrm{~nm}$, while the lowest monthly mean in August, around 0.78.

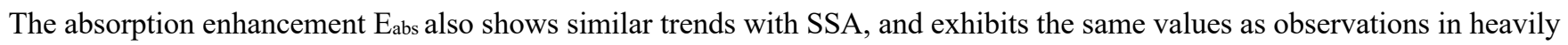
polluted areas. The mean Eabs during the whole BB season is $~ 1.96$ in 2016 and $\sim 2.07$ in 2017. Our observed Eabs is significantly higher than the value $(\sim 1.5)$ commonly adopted by climate models, suggesting the marine boundary layer in the south-eastern Atlantic is more absorbing than the model simulations. Further analysis indicates the contribution of $\mathrm{BrC}$ to absorption is negligible, as $\mathrm{BrC}$ calculated from $\mathrm{AAE}$ are generally around 1-2\% at $464 \mathrm{~nm}$. Although filter samples collected in the boundary layer near the Ascension Island demonstrate the existence of dust aerosols, which can also contribute to the total aerosol absorption, the fraction of dust aerosol is low and unable to explain such high Eabs along. Therefore, we conclude that those high $\mathrm{E}_{\mathrm{abs}}$ mainly resulted from the thick coating of $\mathrm{BC}$ particles, i.e., the lensing effect. By applying the results from theoretical simulation, we estimated the ratio of the shell-core (spherical equivalent particle diameter divided by $\mathrm{BC}$ core diameter) is $\sim 2.2$ on average, suggesting the coating thickness is 1.2 times the $\mathrm{BC}$ core radius for the $\mathrm{BB}$ aerosols observed on the ASI. The monthly variation of SSA and $\mathrm{MAC}_{\mathrm{BC}}$ are found to have a good relationship with $\mathrm{BC} / \triangle \mathrm{CO}$, suggesting that the variation in $\mathrm{BC} / \triangle \mathrm{CO}$ may be responsible for the variation in SSA and $\mathrm{MAC}_{\mathrm{BC}}$ across months during the $\mathrm{BB}$ season. In 
general, both $\mathrm{SSA}$ and $\mathrm{MAC}_{\mathrm{BC}}$ decrease with the increase of $\mathrm{BC} / \Delta \mathrm{CO}$, and this decrease is more dramatic when $\mathrm{BC} / \Delta \mathrm{CO}$ is small $(<0.0034)$.

We further analyse the factors affecting $\mathrm{BC} / \triangle \mathrm{CO}$ and therefore discuss the reasons for the monthly variation in $\mathrm{BC} / \Delta \mathrm{CO}$ during the BB season. From the analysis of fresh smoke, the combustion state (represented by MCE) and BC/ $\triangle \mathrm{CO}$ are linear correlated. Therefore, the change in $\mathrm{BC} / \Delta \mathrm{CO}$ reflects the change in combustion state, i.e., the more flaming, the higher of $\mathrm{BC} / \triangle \mathrm{CO}$. However, due to the long transport time and the extensive clouds underlying the plume layer, we estimate the $\mathrm{BC} / \Delta \mathrm{CO}$ observed on ASI may be subject to aerosol scavenging processes with the transport of the plume. From June to August, mean cloud cover increases in the BB plume transport region with the mean precipitation remaining constant, suggesting that the removal of $\mathrm{BB}$ aerosols by cloud processing may have been increased during this period. Therefore, the observed increase in $\mathrm{BC} / \triangle \mathrm{CO}$ from June to August may be due to changes in combustion conditions, i.e., increasing flaming combustion from June to August. The analysis of the water content of plants shows that the fuel becomes increasingly drier from June to August, which could be the reason for the more flaming combustion. In September and October, mean precipitation increases in the $\mathrm{BB}$ aerosol transport region, thus in addition to the changes in burning conditions, aerosol scavenging also contributes to the decrease in observed $\mathrm{BC} / \Delta \mathrm{CO}$. For the analysis of burning conditions, these two months show an increase in grass burning, along with a decrease in surface wind speed in the burning area during these two months, which may have caused their burning to become more smouldering. However, the above discussion of combustion remains highly uncertain and future work is required to explore the reasons for the change in combustion state and the effect of aerosol scavenging on the $\mathrm{BC} / \Delta \mathrm{CO}$.

Therefore, the correlation of $\mathrm{BC} / \triangle \mathrm{CO}$ with $\mathrm{SSA}$ and $\mathrm{MAC}_{\mathrm{BC}}$ suggest that both $\mathrm{SSA}$ and $\mathrm{MAC}_{\mathrm{BC}}$ decreases when the 505 combustion becomes more flaming $(\mathrm{BC} / \Delta \mathrm{CO}$ increases). This may be because flaming combustion is characterised by a higher concentration of $\mathrm{BC}$ while smouldering is characterised by a higher concentration of scattering $\mathrm{OA}$; hence, the more flaming the combustion is, the lower the SSA. For the $\mathrm{MAC}_{\mathrm{BC}}$, smouldering combustion can result in a smaller $\mathrm{BC}$ core and thicker coating, which could lead to a higher shell-core ratio of $\mathrm{BC}$ particles and thus a higher $\mathrm{MAC}_{\mathrm{BC}}$. We further propose SSA and $\mathrm{MAC}_{\mathrm{BC}}$ can be approximated by either linear or exponential functions with $\mathrm{BC} / \triangle \mathrm{CO}$. Both functions are able to represent the denser data in general, while the exponential function can better capture the rapid growth of SSA as the decrease of $\mathrm{BC} / \Delta \mathrm{CO}$ when $\mathrm{BC} / \Delta \mathrm{CO}<0.003$. These functions provide us with a simple way to estimate the parameters of the aerosol optical characteristics in the south-eastern Atlantic, and can help to improve the parameterisations used in climate models. 


\section{Data availability}

All LASIC ARM data are publicly available at https://www.archive.arm.gov/discovery. The

\section{Author contributions}

$\mathrm{HC}$ and MS developed the concepts and ideas for the direction of the paper. MS, CD, PZ, AS and CF performed the observations and provided the data. All authors contributed to the analysis of the results. HC wrote the paper with input and comments from all other authors.

\section{Competing interests}

The authors declare that they have no conflict of interest.

\section{Special issue statement}

This article is part of the special issue "New observations and related modelling studies of the aerosol- cloud-climate system in the Southeast Atlantic and southern Africa regions (ACP/AMT inter-journal SI)". It is not associated with a conference.

\section{Acknowledgements}

This research has been funded by the Department of Energy (DOE) Atmospheric System Research (ASR) grant DESC0020084, supporting MS and HC. We thank scientists from LASIC campaign for providing observation data. We acknowledge the use of data and from NASA's Fire Information for Resource Management System (FIRMS) 530 (https://earthdata.nasa.gov/firms), part of NASA's Earth Observing System Data and Information System (EOSDIS).

\section{References}

Adachi, K., Chung, S. H., and Buseck, P. R.: Shapes of soot aerosol particles and implications for their effects on climate, Journal of Geophysical Research, 115, D15206, https://doi.org/10.1029/2009jd012868, 2010.

Adebiyi, A. A. and Zuidema, P.: The role of the southern African easterly jet in modifying the southeast Atlantic aerosol and

cloud environments, 142, 1574-1589, https://doi.org/10.1002/qj.2765, 2016.

Adler, G., Riziq, A. A., Erlick, C., and Rudich, Y.: Effect of intrinsic organic carbon on the optical properties of fresh diesel soot, PNAS, 107, 6699-6704, https://doi.org/10.1073/pnas.0903311106, 2010. 
Akagi, S. K., Yokelson, R. J., Wiedinmyer, C., Alvarado, M. J., Reid, J. S., Karl, T., Crounse, J. D., and Wennberg, P. O.: Emission factors for open and domestic biomass burning for use in atmospheric models, 11, 4039-4072, https://doi.org/10.5194/acp-11-4039-2011, 2011.

Akagi, S. K., Craven, J. S., Taylor, J. W., McMeeking, G. R., Yokelson, R. J., Burling, I. R., Urbanski, S. P., Wold, C. E., Seinfeld, J. H., Coe, H., Alvarado, M. J., and Weise, D. R.: Evolution of trace gases and particles emitted by a chaparral fire in California, 12, 1397-1421, https://doi.org/10.5194/acp-12-1397-2012, 2012.

Andreae, M. O.: Emission of trace gases and aerosols from biomass burning - an updated assessment, 19, 8523-8546,

https://doi.org/10.5194/acp-19-8523-2019, 2019.

Andreae, M. O. and Merlet, P.: Emission of trace gases and aerosols from biomass burning, Global Biogeochem. Cycles, 15, 955-966, https://doi.org/10.1029/2000GB001382, 2001.

Bond, T. C. and Bergstrom, R. W.: Light Absorption by Carbonaceous Particles: An Investigative Review, 40, 27-67, https://doi.org/10.1080/02786820500421521, 2006.

550 Bond, T. C., Doherty, S. J., Fahey, D. W., Forster, P. M., Berntsen, T., DeAngelo, B. J., Flanner, M. G., Ghan, S., Kärcher, B., Koch, D., Kinne, S., Kondo, Y., Quinn, P. K., Sarofim, M. C., Schultz, M. G., Schulz, M., Venkataraman, C., Zhang, H., Zhang, S., Bellouin, N., Guttikunda, S. K., Hopke, P. K., Jacobson, M. Z., Kaiser, J. W., Klimont, Z., Lohmann, U., Schwarz, J. P., Shindell, D., Storelvmo, T., Warren, S. G., and Zender, C. S.: Bounding the role of black carbon in the climate system: A scientific assessment, 118, 5380-5552, https://doi.org/10.1002/jgrd.50171, 2013.

555 Brey, S. J., Barnes, E. A., Pierce, J. R., Wiedinmyer, C., and Fischer, E. V.: Environmental Conditions, Ignition Type, and Air Quality Impacts of Wildfires in the Southeastern and Western United States, 6, 1442-1456, https://doi.org/10.1029/2018EF000972, 2018.

Cappa, C. D., Onasch, T. B., Massoli, P., Worsnop, D. R., Bates, T. S., Cross, E. S., Davidovits, P., Hakala, J., Hayden, K. L., Jobson, B. T., Kolesar, K. R., Lack, D. A., Lerner, B. M., Li, S.-M., Mellon, D., Nuaaman, I., Olfert, J. S., Petäjä, T., Quinn, 560 P. K., Song, C., Subramanian, R., Williams, E. J., and Zaveri, R. A.: Radiative Absorption Enhancements Due to the Mixing State of Atmospheric Black Carbon, 337, 1078-1081, https://doi.org/10.1126/science.1223447, 2012.

Cappa, C. D., Zhang, X., Russell, L. M., Collier, S., Lee, A. K. Y., Chen, C.-L., Betha, R., Chen, S., Liu, J., Price, D. J., Sanchez, K. J., McMeeking, G. R., Williams, L. R., Onasch, T. B., Worsnop, D. R., Abbatt, J., and Zhang, Q.: Light Absorption by Ambient Black and Brown Carbon and its Dependence on Black Carbon Coating State for Two California, USA, Cities in

565 Winter and Summer, Journal of Geophysical Research: Atmospheres, 124, 1550-1577, https://doi.org/10.1029/2018JD029501, 2019.

Chakrabarty, R. K. and Heinson, W. R.: Scaling Laws for Light Absorption Enhancement Due to Nonrefractory Coating of Atmospheric Black Carbon Aerosol, Phys. Rev. Lett., 121, 218701, https://doi.org/10.1103/PhysRevLett.121.218701, 2018.

Chand, D., Wood, R., Anderson, T. L., Satheesh, S. K., and Charlson, R. J.: Satellite-derived direct radiative effect of aerosols dependent on cloud cover, 2, 181-184, https://doi.org/10.1038/ngeo437, 2009.

Che, H., Stier, P., Gordon, H., Watson-Parris, D., and Deaconu, L.: Cloud adjustments dominate the overall negative aerosol radiative effects of biomass burning aerosols in UKESM1 climate model simulations over the south-eastern Atlantic, 21, 1733, https://doi.org/10.5194/acp-21-17-2021, 2021. 
Che, H., Segal-Rozenhaimer, M., Zhang, L., Dang, C., Zuidema, P., Dobracki, A., Sedlacek III, A. J., Coe, H., Wu, H., Taylor, J., Jens, R., and Haywood, J.: Cloud processing
the south-eastern Atlantic, In review, 2022a.

Che, H., Stier, P., Watson-Parris, D., Gordon, H., and Deaconu, L.: Source attribution of cloud condensation nuclei and their impact on stratocumulus clouds and radiation in the south-eastern Atlantic, 1-26, https://doi.org/10.5194/acp-2022-43, 2022b.

Chen, J., Li, C., Ristovski, Z., Milic, A., Gu, Y., Islam, M. S., Wang, S., Hao, J., Zhang, H., He, C., Guo, H., Fu, H., Miljevic, B., Morawska, L., Thai, P., Lam, Y. F., Pereira, G., Ding, A., Huang, X., and Dumka, U. C.: A review of biomass burning: Emissions and impacts on air quality, health and climate in China, Science of The Total Environment, 579, 1000-1034, https://doi.org/10.1016/j.scitotenv.2016.11.025, 2017.

Cross, E. S., Onasch, T. B., Ahern, A., Wrobel, W., Slowik, J. G., Olfert, J., Lack, D. A., Massoli, P., Cappa, C. D., Schwarz, J. P., Spackman, J. R., Fahey, D. W., Sedlacek, A., Trimborn, A., Jayne, J. T., Freedman, A., Williams, L. R., Ng, N. L., 585 Mazzoleni, C., Dubey, M., Brem, B., Kok, G., Subramanian, R., Freitag, S., Clarke, A., Thornhill, D., Marr, L. C., Kolb, C. E., Worsnop, D. R., and Davidovits, P.: Soot Particle Studies-Instrument Inter-Comparison-Project Overview, Aerosol Science and Technology, 44, 592-611, https://doi.org/10.1080/02786826.2010.482113, 2010.

Dang, C., Segal-Rozenhaimer, M., Che, H., Zhang, L., Formenti, P., Taylor, J., Dobracki, A., Purdue, S., Wong, P.-S., Nenes, A., Sedlacek, A., Coe, H., Redemann, J., Zuidema, P., and Haywood, J.: Biomass burning and marine aerosol processing over the southeast Atlantic Ocean: A TEM single particle analysis, 1-30, https://doi.org/10.5194/acp-2021-724, 2021.

Denjean, C., Brito, J., Libois, Q., Mallet, M., Bourrianne, T., Burnet, F., Dupuy, R., Flamant, C., and Knippertz, P.: Unexpected Biomass Burning Aerosol Absorption Enhancement Explained by Black Carbon Mixing State, 47, e2020GL089055, https://doi.org/10.1029/2020GL089055, 2020.

Diamond, M. S., Dobracki, A., Freitag, S., Small Griswold, J. D., Heikkila, A., Howell, S. G., Kacarab, M. E., Podolske, J. R., 595 Saide, P. E., and Wood, R.: Time-dependent entrainment of smoke presents an observational challenge for assessing aerosolcloud interactions over the southeast Atlantic Ocean, 18, 14623-14636, https://doi.org/10.5194/acp-18-14623-2018, 2018.

Doherty, S. J., Saide, P. E., Zuidema, P., Shinozuka, Y., Ferrada, G. A., Gordon, H., Mallet, M., Meyer, K., Painemal, D., Howell, S. G., Freitag, S., Dobracki, A., Podolske, J. R., Burton, S. P., Ferrare, R. A., Howes, C., Nabat, P., Carmichael, G. R., da Silva, A., Pistone, K., Chang, I., Gao, L., Wood, R., and Redemann, J.: Modeled and observed properties related to the 600 direct aerosol radiative effect of biomass burning aerosol over the southeastern Atlantic, 22, 1-46, https://doi.org/10.5194/acp22-1-2022, 2022.

Eck, T. F., Holben, B. N., Reid, J. S., Mukelabai, M. M., Piketh, S. J., Torres, O., Jethva, H. T., Hyer, E. J., Ward, D. E., Dubovik, O., Sinyuk, A., Schafer, J. S., Giles, D. M., Sorokin, M., Smirnov, A., and Slutsker, I.: A seasonal trend of single scattering albedo in southern African biomass-burning particles: Implications for satellite products and estimates of emissions

605 for the world's largest biomass-burning source, J. Geophys. Res. Atmos., 118, 6414-6432, https://doi.org/10.1002/jgrd.50500, 2013.

Eswaran, K., Satheesh, S. K., and Srinivasan, J.: Multi-satellite retrieval of single scattering albedo using the OMI-MODIS algorithm, 19, 3307-3324, https://doi.org/10.5194/acp-19-3307-2019, 2019.

Freire, J. L. M., Longo, K. M., Freitas, S. R., Coelho, C. A. S., Molod, A. M., Marshak, J., Silva, A. da, and Ribeiro, B. Z.: To 610 What Extent Biomass Burning Aerosols Impact South America Seasonal Climate Predictions?, 47, e2020GL088096, https://doi.org/10.1029/2020GL088096, 2020. 
Giglio, L., Schroeder, W., and Justice, C. O.: The collection 6 MODIS active fire detection algorithm and fire products, Remote Sensing of Environment, 178, 31-41, https://doi.org/10.1016/j.rse.2016.02.054, 2016.

Gordon, H., Field, P. R., Abel, S. J., Dalvi, M., Grosvenor, D. P., Hill, A. A., Johnson, B. T., Miltenberger, A. K., Yoshioka, 615 M., and Carslaw, K. S.: Large simulated radiative effects of smoke in the south-east Atlantic, 18, 15261-15289, https://doi.org/10.5194/acp-18-15261-2018, 2018.

Guenther, A., Karl, T., Harley, P., Wiedinmyer, C., Palmer, P. I., and Geron, C.: Estimates of global terrestrial isoprene emissions using MEGAN (Model of Emissions of Gases and Aerosols from Nature), Atmospheric Chemistry and Physics, 6, 3181-3210, 2006.

620 Haywood, J. M., Osborne, S. R., and Abel, S. J.: The effect of overlying absorbing aerosol layers on remote sensing retrievals of cloud effective radius and cloud optical depth, 130, 779-800, https://doi.org/10.1256/qj.03.100, 2004.

Haywood, J. M., Abel, S. J., Barrett, P. A., Bellouin, N., Blyth, A., Bower, K. N., Brooks, M., Carslaw, K., Che, H., Coe, H., Cotterell, M. I., Crawford, I., Cui, Z., Davies, N., Dingley, B., Field, P., Formenti, P., Gordon, H., de Graaf, M., Herbert, R., Johnson, B., Jones, A. C., Langridge, J. M., Malavelle, F., Partridge, D. G., Peers, F., Redemann, J., Stier, P., Szpek, K., 625 Taylor, J. W., Watson-Parris, D., Wood, R., Wu, H., and Zuidema, P.: The CLoud-Aerosol-Radiation Interaction and Forcing: Year 2017 (CLARIFY-2017) measurement campaign, 21, 1049-1084, https://doi.org/10.5194/acp-21-1049-2021, 2021.

Hennigan, C. J., Miracolo, M. A., Engelhart, G. J., May, A. A., Presto, A. A., Lee, T., Sullivan, A. P., McMeeking, G. R., Coe, H., Wold, C. E., Hao, W.-M., Gilman, J. B., Kuster, W. C., de Gouw, J., Schichtel, B. A., Collett, J. L. J., Kreidenweis, S. M., and Robinson, A. L.: Chemical and physical transformations of organic aerosol from the photo-oxidation of open biomass burning emissions in an environmental chamber, 11, 7669-7686, https://doi.org/10.5194/acp-11-7669-2011, 2011.

Hersbach, H., Bell, B., Berrisford, P., Hirahara, S., Horányi, A., Muñoz-Sabater, J., Nicolas, J., Peubey, C., Radu, R., Schepers, D., Simmons, A., Soci, C., Abdalla, S., Abellan, X., Balsamo, G., Bechtold, P., Biavati, G., Bidlot, J., Bonavita, M., Chiara, G. D., Dahlgren, P., Dee, D., Diamantakis, M., Dragani, R., Flemming, J., Forbes, R., Fuentes, M., Geer, A., Haimberger, L., Healy, S., Hogan, R. J., Hólm, E., Janisková, M., Keeley, S., Laloyaux, P., Lopez, P., Lupu, C., Radnoti, G., Rosnay, P. de,

635 Rozum, I., Vamborg, F., Villaume, S., and Thépaut, J.-N.: The ERA5 global reanalysis, 146, 1999-2049, https://doi.org/10.1002/qj.3803, 2020.

Jiang, H., Xue, H., Teller, A., Feingold, G., and Levin, Z.: Aerosol effects on the lifetime of shallow cumulus, 33, https://doi.org/10.1029/2006GL026024, 2006.

Johnson, B. T., Osborne, S. R., Haywood, J. M., and Harrison, M. a. J.: Aircraft measurements of biomass burning aerosol over West Africa during DABEX, 113, https://doi.org/10.1029/2007JD009451, 2008.

Johnston, F. H., Henderson, S. B., Chen, Y., Randerson, J. T., Marlier, M., Defries, R. S., Kinney, P., Bowman, D. M. J. S., and Brauer, M.: Estimated global mortality attributable to smoke from landscape fires, Environ Health Perspect, 120, 695701, https://doi.org/10.1289/ehp.1104422, 2012.

Karaca, F., Anil, I., and Alagha, O.: Long-range potential source contributions of episodic aerosol events to PM10 profile of a megacity, Atmospheric Environment, 43, 5713-5722, https://doi.org/10.1016/j.atmosenv.2009.08.005, 2009.

Koçak, M., Mihalopoulos, N., and Kubilay, N.: Origin and source regions of PM10 in the Eastern Mediterranean atmosphere, Atmospheric Research, 92, 464-474, https://doi.org/10.1016/j.atmosres.2009.01.005, 2009. 
Lack, D. A. and Langridge, J. M.: On the attribution of black and brown carbon light absorption using the Ångström exponent, 13, 10535-10543, https://doi.org/10.5194/acp-13-10535-2013, 2013.

650 Liu, C., Chung, C. E., Yin, Y., and Schnaiter, M.: The absorption Ångström exponent of black carbon: from numerical aspects, 18, 6259-6273, https://doi.org/10.5194/acp-18-6259-2018, 2018.

Liu, S., Aiken, A. C., Gorkowski, K., Dubey, M. K., Cappa, C. D., Williams, L. R., Herndon, S. C., Massoli, P., Fortner, E. C., Chhabra, P. S., Brooks, W. A., Onasch, T. B., Jayne, J. T., Worsnop, D. R., China, S., Sharma, N., Mazzoleni, C., Xu, L., Ng, N. L., Liu, D., Allan, J. D., Lee, J. D., Fleming, Z. L., Mohr, C., Zotter, P., Szidat, S., and Prévôt, A. S. H.: Enhanced light

655 absorption by mixed source black and brown carbon particles in UK winter, 6, 8435, https://doi.org/10.1038/ncomms9435, 2015 .

Lu, Z., Liu, X., Zhang, Z., Zhao, C., Meyer, K., Rajapakshe, C., Wu, C., Yang, Z., and Penner, J. E.: Biomass smoke from southern Africa can significantly enhance the brightness of stratocumulus over the southeastern Atlantic Ocean, PNAS, 115, 2924-2929, https://doi.org/10.1073/pnas.1713703115, 2018.

660 Malavelle, F. F., Haywood, J. M., Mercado, L. M., Folberth, G. A., Bellouin, N., Sitch, S., and Artaxo, P.: Studying the impact of biomass burning aerosol radiative and climate effects on the Amazon rainforest productivity with an Earth system model, 19, 1301-1326, https://doi.org/10.5194/acp-19-1301-2019, 2019.

Mallet, M., Solmon, F., Nabat, P., Elguindi, N., Waquet, F., Bouniol, D., Sayer, A. M., Meyer, K., Roehrig, R., Michou, M., Zuidema, P., Flamant, C., Redemann, J., and Formenti, P.: Direct and semi-direct radiative forcing of biomass-burning aerosols

665 over the southeast Atlantic (SEA) and its sensitivity to absorbing properties: a regional climate modeling study, 20, 1319113216, https://doi.org/10.5194/acp-20-13191-2020, 2020.

Mallet, M., Nabat, P., Johnson, B., Michou, M., Haywood, J. M., Chen, C., and Dubovik, O.: Climate models generally underrepresent the warming by Central Africa biomass-burning aerosols over the Southeast Atlantic, https://doi.org/10.1126/sciadv.abg9998, 2021.

670 May, A. A., McMeeking, G. R., Lee, T., Taylor, J. W., Craven, J. S., Burling, I., Sullivan, A. P., Akagi, S., Collett, J. L., Flynn, M., Coe, H., Urbanski, S. P., Seinfeld, J. H., Yokelson, R. J., and Kreidenweis, S. M.: Aerosol emissions from prescribed fires in the United States: A synthesis of laboratory and aircraft measurements, 119, 11,826-11,849, https://doi.org/10.1002/2014JD021848, 2014.

McComiskey, A., Schwartz, S., Schmid, B., Guan, H., Lewis, E., Ricchiazzi, P., and Ogren, J.: Direct aerosol forcing: 675 Calculation from observables and sensitivities to inputs, Journal of Geophysical Research, 113, D09202, https://doi.org/10.1029/2007JD009170, 2008.

Naeher, L. P., Brauer, M., Lipsett, M., Zelikoff, J. T., Simpson, C. D., Koenig, J. Q., and Smith, K. R.: Woodsmoke health effects: a review, Inhal Toxicol, 19, 67-106, https://doi.org/10.1080/08958370600985875, 2007.

Ogren, J. A.: Comment on "Calibration and Intercomparison of Filter-Based Measurements of Visible Light Absorption by Aerosols," 44, 589-591, https://doi.org/10.1080/02786826.2010.482111, 2010.

Peng, J., Hu, M., Guo, S., Du, Z., Zheng, J., Shang, D., Levy Zamora, M., Zeng, L., Shao, M., Wu, Y.-S., Zheng, J., Wang, Y., Glen, C. R., Collins, D. R., Molina, M. J., and Zhang, R.: Markedly enhanced absorption and direct radiative forcing of black carbon under polluted urban environments, Proc Natl Acad Sci USA, 113, 4266-4271, https://doi.org/10.1073/pnas.1602310113, 2016. 
Pistone, K., Redemann, J., Doherty, S., Zuidema, P., Burton, S., Cairns, B., Cochrane, S., Ferrare, R., Flynn, C., Freitag, S., Howell, S. G., Kacenelenbogen, M., LeBlanc, S., Liu, X., Schmidt, K. S., Sedlacek III, A. J., Segal-Rozenhaimer, M., Shinozuka, Y., Stamnes, S., Diedenhoven, B. van, Harten, G. V., and Xu, F.: Intercomparison of biomass burning aerosol optical properties from in situ and remote-sensing instruments in ORACLES-2016, 19, 9181-9208, https://doi.org/10.5194/acp-19-9181-2019, 2019.

690 Pokhrel, R. P., Wagner, N. L., Langridge, J. M., Lack, D. A., Jayarathne, T., Stone, E. A., Stockwell, C. E., Yokelson, R. J., and Murphy, S. M.: Parameterization of single-scattering albedo (SSA) and absorption Ångström exponent (AAE) with EC / OC for aerosol emissions from biomass burning, 16, 9549-9561, https://doi.org/10.5194/acp-16-9549-2016, 2016.

Pokhrel, R. P., Gordon, J., Fiddler, M. N., and Bililign, S.: Impact of combustion conditions on physical and morphological properties of biomass burning aerosol, 55, 80-91, https://doi.org/10.1080/02786826.2020.1822512, 2021.

695 Polissar, A. V., Hopke, P. K., and Harris, J. M.: Source Regions for Atmospheric Aerosol Measured at Barrow, Alaska, Environ. Sci. Technol., 35, 4214-4226, https://doi.org/10.1021/es0107529, 2001.

Redemann, J., Wood, R., Zuidema, P., Doherty, S. J., Luna, B., LeBlanc, S. E., Diamond, M. S., Shinozuka, Y., Chang, I. Y., Ueyama, R., Pfister, L., Ryoo, J.-M., Dobracki, A. N., da Silva, A. M., Longo, K. M., Kacenelenbogen, M. S., Flynn, C. J., Pistone, K., Knox, N. M., Piketh, S. J., Haywood, J. M., Formenti, P., Mallet, M., Stier, P., Ackerman, A. S., Bauer, S. E., 700 Fridlind, A. M., Carmichael, G. R., Saide, P. E., Ferrada, G. A., Howell, S. G., Freitag, S., Cairns, B., Holben, B. N., Knobelspiesse, K. D., Tanelli, S., L’Ecuyer, T. S., Dzambo, A. M., Sy, O. O., McFarquhar, G. M., Poellot, M. R., Gupta, S., O’Brien, J. R., Nenes, A., Kacarab, M., Wong, J. P. S., Small-Griswold, J. D., Thornhill, K. L., Noone, D., Podolske, J. R., Schmidt, K. S., Pilewskie, P., Chen, H., Cochrane, S. P., Sedlacek, A. J., Lang, T. J., Stith, E., Segal-Rozenhaimer, M., Ferrare, R. A., Burton, S. P., Hostetler, C. A., Diner, D. J., Seidel, F. C., Platnick, S. E., Myers, J. S., Meyer, K. G., Spangenberg, D.

705 A., Maring, H., and Gao, L.: An overview of the ORACLES (ObseRvations of Aerosols above CLouds and their intEractionS) project: aerosol-cloud-radiation interactions in the southeast Atlantic basin, 21, 1507-1563, https://doi.org/10.5194/acp-211507-2021, 2021.

Reisen, F., Meyer, C. P. (Mick), and Keywood, M. D.: Impact of biomass burning sources on seasonal aerosol air quality, Atmospheric Environment, 67, 437-447, https://doi.org/10.1016/j.atmosenv.2012.11.004, 2013.

710 Roberts, G., Wooster, M. J., and Lagoudakis, E.: Annual and diurnal african biomass burning temporal dynamics, 6, 849-866, https://doi.org/10.5194/bg-6-849-2009, 2009.

Roberts, J. M., Veres, P. R., Cochran, A. K., Warneke, C., Burling, I. R., Yokelson, R. J., Lerner, B., Gilman, J. B., Kuster, W. C., Fall, R., and Gouw, J. de: Isocyanic acid in the atmosphere and its possible link to smoke-related health effects, PNAS, 108, 8966-8971, https://doi.org/10.1073/pnas.1103352108, 2011.

715 Sakaeda, N., Wood, R., and Rasch, P. J.: Direct and semidirect aerosol effects of southern African biomass burning aerosol, Journal of Geophysical Research: Atmospheres, 116, https://doi.org/10.1029/2010JD015540, 2011.

Santoso, M. A., Christensen, E. G., Yang, J., and Rein, G.: Review of the Transition From Smouldering to Flaming Combustion in Wildfires, Front. Mech. Eng., 0, https://doi.org/10.3389/fmech.2019.00049, 2019.

Stein, A. F., Draxler, R. R., Rolph, G. D., Stunder, B. J. B., Cohen, M. D., and Ngan, F.: NOAA's HYSPLIT Atmospheric

Transport and Dispersion Modeling System, 96, 2059-2077, https://doi.org/10.1175/BAMS-D-14-00110.1, 2015.

Stier, P., Schutgens, N. A. J., Bellouin, N., Bian, H., Boucher, O., Chin, M., Ghan, S., Huneeus, N., Kinne, S., Lin, G., Ma, X., Myhre, G., Penner, J. E., Randles, C. A., Samset, B., Schulz, M., Takemura, T., Yu, F., Yu, H., and Zhou, C.: Host model 
uncertainties in aerosol forcing estimates: results from the AeroCom Prescribed intercomparison study, Atmospheric Chemistry and Physics, 13, 3245-3270, https://doi.org/10.5194/acp-13-3245-2013, 2013.

725 Sulla-Menashe, D., Gray, J. M., Abercrombie, S. P., and Friedl, M. A.: Hierarchical mapping of annual global land cover 2001 to present: The MODIS Collection 6 Land Cover product, Remote Sensing of Environment, 222, 183-194, https://doi.org/10.1016/j.rse.2018.12.013, 2019.

Taylor, J. W., Choularton, T. W., Blyth, A. M., Flynn, M. J., Williams, P. I., Young, G., Bower, K. N., Crosier, J., Gallagher, M. W., Dorsey, J. R., Liu, Z., and Rosenberg, P. D.: Aerosol measurements during COPE: composition, size, and sources of

$730 \mathrm{CCN}$ and INPs at the interface between marine and terrestrial influences, Atmos. Chem. Phys., 16, 11687-11709, https://doi.org/10.5194/acp-16-11687-2016, 2016.

Taylor, J. W., Wu, H., Szpek, K., Bower, K., Crawford, I., Flynn, M. J., Williams, P. I., Dorsey, J., Langridge, J. M., Cotterell, M. I., Fox, C., Davies, N. W., Haywood, J. M., and Coe, H.: Absorption closure in highly aged biomass burning smoke, 20, 11201-11221, https://doi.org/10.5194/acp-20-11201-2020, 2020.

735 Textor, C., Schulz, M., Guibert, S., Kinne, S., Balkanski, Y., Bauer, S., Berntsen, T., Berglen, T., Boucher, O., Chin, M., Dentener, F., Diehl, T., Easter, R., Feichter, H., Fillmore, D., Ghan, S., Ginoux, P., Gong, S., Grini, A., Hendricks, J., Horowitz, L., Huang, P., Isaksen, I., Iversen, I., Kloster, S., Koch, D., Kirkevåg, A., Kristjansson, J. E., Krol, M., Lauer, A., Lamarque, J. F., Liu, X., Montanaro, V., Myhre, G., Penner, J., Pitari, G., Reddy, S., Seland, Ø., Stier, P., Takemura, T., and Tie, X.: Analysis and quantification of the diversities of aerosol life cycles within AeroCom, 6, 1777-1813, 740 https://doi.org/10.5194/acp-6-1777-2006, 2006.

Thornhill, G. D., Ryder, C. L., Highwood, E. J., Shaffrey, L. C., and Johnson, B. T.: The effect of South American biomass burning aerosol emissions on the regional climate, 18, 5321-5342, https://doi.org/10.5194/acp-18-5321-2018, 2018.

Vakkari, V., Beukes, J. P., Dal Maso, M., Aurela, M., Josipovic, M., and van Zyl, P. G.: Major secondary aerosol formation in southern African open biomass burning plumes, 11, 580-583, https://doi.org/10.1038/s41561-018-0170-0, 2018.

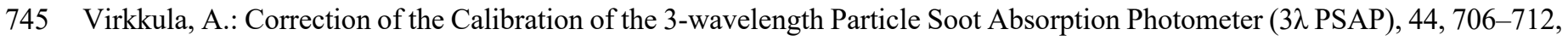
https://doi.org/10.1080/02786826.2010.482110, 2010.

Wang, Q., Jacob, D. J., Spackman, J. R., Perring, A. E., Schwarz, J. P., Moteki, N., Marais, E. A., Ge, C., Wang, J., and Barrett, S. R. H.: Global budget and radiative forcing of black carbon aerosol: Constraints from pole-to-pole (HIPPO) observations across the Pacific, 119, 195-206, https://doi.org/10.1002/2013JD020824, 2014.

750 Wang, Y., Liu, F., He, C., Bi, L., Cheng, T., Wang, Z., Zhang, H., Zhang, X., Shi, Z., and Li, W.: Fractal Dimensions and Mixing Structures of Soot Particles during Atmospheric Processing, Environ. Sci. Technol. Lett., 4, 487-493, https://doi.org/10.1021/acs.estlett.7b00418, 2017.

van der Werf, G. R., Randerson, J. T., Giglio, L., van Leeuwen, T. T., Chen, Y., Rogers, B. M., Mu, M., van Marle, M. J. E., Morton, D. C., Collatz, G. J., Yokelson, R. J., and Kasibhatla, P. S.: Global fire emissions estimates during 1997-2016, 9, 697-720, https://doi.org/10.5194/essd-9-697-2017, 2017.

Wilcox, E. M.: Direct and semi-direct radiative forcing of smoke aerosols over clouds, 12, 139-149, https://doi.org/10.5194/acp-12-139-2012, 2012.

Wilson, E. H. and Sader, S. A.: Detection of forest harvest type using multiple dates of Landsat TM imagery, Remote Sensing of Environment, 80, 385-396, https://doi.org/10.1016/S0034-4257(01)00318-2, 2002. 
760 Wu, H., Taylor, J. W., Szpek, K., Langridge, J. M., Williams, P. I., Flynn, M., Allan, J. D., Abel, S. J., Pitt, J., Cotterell, M. I., Fox, C., Davies, N. W., Haywood, J., and Coe, H.: Vertical variability of the properties of highly aged biomass burning aerosol transported over the southeast Atlantic during CLARIFY-2017, 20, 12697-12719, https://doi.org/10.5194/acp-20-12697$2020,2020$.

Xie, C., Xu, W., Wang, J., Liu, D., Ge, X., Zhang, Q., Wang, Q., Du, W., Zhao, J., Zhou, W., Li, J., Fu, P., Wang, Z., Worsnop,

765 D., and Sun, Y.: Light absorption enhancement of black carbon in urban Beijing in summer, Atmospheric Environment, 213, 499-504, https://doi.org/10.1016/j.atmosenv.2019.06.041, 2019.

Xu, X., Zhao, W., Qian, X., Wang, S., Fang, B., Zhang, Q., Zhang, W., Venables, D. S., Chen, W., Huang, Y., Deng, X., Wu, B., Lin, X., Zhao, S., and Tong, Y.: The influence of photochemical aging on light absorption of atmospheric black carbon and aerosol single-scattering albedo, 18, 16829-16844, https://doi.org/10.5194/acp-18-16829-2018, 2018.

770 Yokelson, R. J., Crounse, J. D., DeCarlo, P. F., Karl, T., Urbanski, S., Atlas, E., Campos, T., Shinozuka, Y., Kapustin, V., Clarke, A. D., Weinheimer, A., Knapp, D. J., Montzka, D. D., Holloway, J., Weibring, P., Flocke, F., Zheng, W., Toohey, D., Wennberg, P. O., Wiedinmyer, C., Mauldin, L., Fried, A., Richter, D., Walega, J., Jimenez, J. L., Adachi, K., Buseck, P. R., Hall, S. R., and Shetter, R.: Emissions from biomass burning in the Yucatan, 9, 5785-5812, https://doi.org/10.5194/acp-95785-2009, 2009.

775 Zhang, J. and Zuidema, P.: Sunlight-absorbing aerosol amplifies the seasonal cycle in low-cloud fraction over the southeast Atlantic, 21, 11179-11199, https://doi.org/10.5194/acp-21-11179-2021, 2021.

Zhang, L., Segal-Rozenhaimer, M., Che, H., Dang, C., Sedlacek III, A. J., Lewis, E. R., Dobracki, A., Wong, J. P. S., Formenti, P., Howell, S. G., and Nenes, A.: Light Absorption by Brown Carbon over the South-East Atlantic Ocean, 1-24, https://doi.org/10.5194/acp-2021-1000, 2022.

780 Zhang, X., Mao, M., Yin, Y., and Wang, B.: Absorption enhancement of aged black carbon aerosols affected by their microphysics: A numerical investigation, Journal of Quantitative Spectroscopy and Radiative Transfer, 202, 90-97, https://doi.org/10.1016/j.jqsrt.2017.07.025, 2017.

Zhang, X. L., Wu, G. J., Zhang, C. L., Xu, T. L., and Zhou, Q. Q.: What is the real role of iron oxides in the optical properties of dust aerosols?, 15, 12159-12177, https://doi.org/10.5194/acp-15-12159-2015, 2015.

785 Zuidema, P., Redemann, J., Haywood, J., Wood, R., Piketh, S., Hipondoka, M., and Formenti, P.: Smoke and Clouds above the Southeast Atlantic: Upcoming Field Campaigns Probe Absorbing Aerosol's Impact on Climate, Bull. Amer. Meteor. Soc., 97, 1131-1135, https://doi.org/10.1175/BAMS-D-15-00082.1, 2016.

Zuidema, P., Alvarado, M., Chiu, C., DeSzoeke, S., Fairall, C., Feingold, G., Freedman, A., Ghan, S., Haywood, J., Kollias, P., Lewis, E., McFarquhar, G., McComiskey, A., Mechem, D., Onasch, T., Redemann, J., Romps, D., and Turner, D.: Layered Atlantic Smoke Interactions with Clouds (LASIC) Field Campaign Report, 47, $2018 \mathrm{a}$.

Zuidema, P., Sedlacek, A. J., Flynn, C., Springston, S., Delgadillo, R., Zhang, J., Aiken, A. C., Koontz, A., and Muradyan, P.: The Ascension Island Boundary Layer in the Remote Southeast Atlantic is Often Smoky, 45, 4456-4465, https://doi.org/10.1002/2017GL076926, 2018b. 